(c) American Dairy Science Association, 2002.

\title{
Peripartum Performance and Metabolism of Dairy Cows in Response to Prepartum Energy and Protein Intake
}

\author{
L. Doepel, ${ }^{\star}$ H. Lapierre,† and J. J. Kennelly* \\ *Department of Agricultural, Food and Nutritional Science, \\ University of Alberta, Edmonton, T6G 2P5 \\ †Dairy and Swine Research and Development Centre, \\ Agriculture and Agri-Food Canada, Lennoxville, QC, J1M 1 Z3
}

\begin{abstract}
Twenty-six multiparous Holstein cows were used to examine the effects of prepartum energy and protein intake on periparturient metabolism and lactation performance. Two levels of energy, $1.65 \mathrm{Mcal} / \mathrm{kg}$ of net energy for lactation $\left(\mathrm{NE}_{\mathrm{L}}\right)$ and $1.30 \mathrm{Mcal} / \mathrm{kg}$ of $\mathrm{NE}_{\mathrm{L}}$, and two levels of protein, $17.0 \% \mathrm{CP}$ and $12.5 \% \mathrm{CP}$, were tested according to a factorial arrangement in a randomized block design. Dietary treatments were fed ad libitum from $21 \mathrm{~d}$ before expected calving date to the day of calving. After calving, all cows were fed the same diet. Increased nutrient density did not affect prepartum feed intake, but postpartum intake was higher for cows fed the high-energy diets. Treatment had no effect on cow body weight and body condition score, however, cows fed the high-energy diets were in greater energy balance throughout the study. Milk and milk component yields were unaffected by treatment. Cows fed the high-energy diets had lower plasma nonesterified fatty acid concentrations than cows fed the low energy diets (354.3 vs. $439.9 \mu \mathrm{mol} /$ L). Hepatic triglyceride concentrations were lower for cows on the high-energy diets than for those on the low-energy diets. Liver glycogen was unaffected by treatment. Acetyl-CoA carboxylase and fatty acid synthase abundance was significantly lower at calving than pretreatment, and higher for cows on the highenergy diets relative to those on the low-energy diets. The activity of acetyl-CoA carboxylase and lipoprotein lipase was greatly decreased with the onset of lactation. Increased protein intake prepartum resulted in elevated plasma $\beta$-hydroxybutyrate concentrations postpartum. Prepartum plasma urea nitrogen was increased and 3-methylhistidine decreased by the high protein treatments. Overall, increased energy density of prepartum diets had beneficial effects on feed intake
\end{abstract}

Received December 7, 2001.

Accepted February 20, 2002.

Corresponding author: J. J. Kennelly; e-mail: John. Kennelly@ ualberta.ca. and lipid metabolism but did not improve lactation performance. Increasing the protein content of the prepartum diet did not appear to confer any advantages to cow productivity.

(Key words: energy, protein, transition cow, lipid metabolism)

Abbreviation key: ACC = acetyl-CoA carboxylase, EAA = essential amino acid, FA = fatty acid, FAS = fatty acid synthase, $\mathbf{G H}=$ growth hormone, $\mathbf{H E}=$ high energy, $\mathbf{H P}=$ high protein, $\mathbf{K I}=$ ketosis induction, $\mathbf{L E}$ = low energy, $\mathbf{L P}=$ low protein, $\mathbf{L P L}=$ lipoprotein lipase, NEAA = nonessential amino acid, PUN = plasma urea nitrogen, 3-MH = 3-methylhistidine, TG $=$ triglyceride.

\section{INTRODUCTION}

The transition period for dairy cows, defined as 3 wk precalving to 3 wk postcalving (Grummer, 1995), is the most critical phase of the lactation cycle. This period is characterized by a substantial decline in feed intake around parturition (Bertics et al., 1992), lipid mobilization leading to elevated plasma NEFA and hepatic triglyceride (TG) content (Vázquez-Añón et al., 1994), protein mobilization as evidenced by increased urinary 3-methylhistidine:creatinine ratios (VandeHaar et al., 1999), and endocrinological changes in support of parturition and lactogenesis (Grummer, 1993). When feed intake is severely reduced, the dependence on lipid stores increases, with a subsequent increase in the probability of hepatic lipidosis and metabolic disorders developing (Goff and Horst, 1997). Increasing the nutrient density of the diet may offset the negative effects of reduced intake observed before parturition. Feeding prepartum diets that are more energy dense than that recommended by NRC (1989) has led to reductions in both plasma NEFA concentrations and lipid infiltration of the liver (VandeHaar et al., 1999). Similarly, when prepartum diets containing higher levels of protein than that recommended by NRC (1989) have been fed, there have been improvements in metabolic status of the cows 
(Putnam and Varga, 1998) and BCS (Van Saun et al., 1993). However, in the majority of studies when prepartum diet nutrient density has been increased, there have been no or minimal responses in milk production (Putnam and Varga, 1998; Huyler et al., 1999; Putnam et al., 1999). In most cases, when the effects of protein level have been examined, energy density of the diet has been kept constant; perhaps energy limitations are preventing any beneficial effects of additional protein from being fully expressed. A similar situation may exist when energy supply is increased but protein content is held constant. Consequently, our objective was to examine the effects of prepartum diets with two energy densities in conjunction with two protein densities in a factorial arrangement on lipid and protein metabolism, and lactation performance.

\section{MATERIALS AND METHODS}

\section{Animals and Treatments}

Twenty-eight Holstein cows entering their second or third lactation were used. Cows were blocked by parity, milk production, and expected calving date, and were randomly assigned within each block to one of four dietary treatments-high energy-high protein (HEHP), high energy-low protein (HELP), low energy-high protein (LEHP), and low energy-low protein (LELP). The four dietary treatments were arranged as a $2 \times 2$ factorial, with two levels of energy, 1.65 $\mathrm{Mcal} / \mathrm{kg}$ of $\mathrm{NE}_{\mathrm{L}}(\mathbf{H E})$ and $1.30 \mathrm{Mcal} / \mathrm{kg}$ of $\mathrm{NE}_{\mathrm{L}}(\mathbf{L E})$ and two levels of CP, $17.0 \%(\mathbf{H P})$ and $12.5 \%(\mathbf{L P})$. Ingredient and nutrient composition of the diets is shown in Table 1. Forage $\mathrm{NE}_{\mathrm{L}}$ content was calculated from Minnesota Valley Testing Laboratories: [1.044 $(0.0123 \times \mathrm{ADF})] \times 2.2046$ for legumes, $[1.085-(0.015$ $\times \mathrm{ADF})] \times 2.2046$ for grasses, and $2.072-(0.0176 \times$ $\mathrm{ADF}$ ) for barley silage, where $\mathrm{NE}_{\mathrm{L}}$ density is in Mcal/ $\mathrm{kg}$, and $\mathrm{ADF}$ is in percentage of $\mathrm{DM}$. The $\mathrm{NE}_{\mathrm{L}}$ content of the concentrates was based on NRC values (1989). Based on an estimated DMI of $13 \mathrm{~kg} / \mathrm{d}$, and using NRC (2001) equations, $\mathrm{NE}_{\mathrm{L}}$ density of the diets would be $1.66,1.60,1.39$, and $1.33 \mathrm{Mcal} / \mathrm{kg} \mathrm{DM}$ for HEHP, HELP, LEHP, and LELP, respectively. Diets were formulated using the Cornell Net Carbohydrate and Protein System (O'Connor et al., 1993) to supply similar amounts of metabolizable protein from the two HP diets and from the two LP diets. Based on $13 \mathrm{~kg} / \mathrm{d}$ of DMI, metabolizable protein supply was calculated (NRC, 2001) to be 1466, 1017, 1523, and $1061 \mathrm{~g} / \mathrm{d}$ for HEHP, HELP, LEHP, and LELP, respectively.

Cows were purchased for this study in late lactation (>280 DIM). While lactating, all the cows were fed a late-lactation diet consisting of $11.8 \%$ alfalfa hay, $16.8 \%$ alfalfa silage, $26.4 \%$ barley silage, and $45 \%$
Table 1. Ingredient and nutrient composition of prepartum dietary treatments (DM basis).

\begin{tabular}{|c|c|c|c|c|}
\hline & \multicolumn{4}{|c|}{ Treatments $^{1}$} \\
\hline & HEHP & HELP & LEHP & LELP \\
\hline \multicolumn{5}{|c|}{ Ingredient composition (\%) } \\
\hline Alfalfa silage & 6.4 & 6.5 & 6.2 & 6.3 \\
\hline Barley silage & 32.9 & 32.4 & 10.5 & 11.0 \\
\hline Grass hay & 17.2 & 13.1 & 31.5 & 30.5 \\
\hline Oat hulls & $\ldots$ & 4.9 & 28.1 & 30.8 \\
\hline Beet pulp & 8.8 & 8.9 & 3.4 & 3.3 \\
\hline Rolled barley & 19.2 & 28.3 & 6.0 & 11.5 \\
\hline Canola meal & 2.5 & 0.4 & 1.3 & 0.4 \\
\hline Soybean meal & 2.5 & 0.4 & 1.6 & 1.5 \\
\hline Corn gluten meal & 2.5 & 0.4 & 2.8 & 1.0 \\
\hline Blood meal & 3.4 & & 6.1 & 1.0 \\
\hline Tallow & 2.2 & 2.2 & & \\
\hline Vitamin $\mathrm{ADE}^{2}$ & 1.04 & 1.04 & 1.04 & 1.04 \\
\hline Magnesium oxide & 0.22 & 0.22 & 0.22 & 0.22 \\
\hline Trace mineral mix $^{3}$ & 0.81 & 0.81 & 0.81 & 0.81 \\
\hline Dicalcium phosphate & 0.07 & 0.15 & 0.15 & 0.22 \\
\hline Limestone & 0.15 & 0.22 & 0.22 & 0.30 \\
\hline \multirow{2}{*}{\multicolumn{5}{|c|}{ Nutrient composition ${ }^{4}$}} \\
\hline & & & & \\
\hline $\mathrm{DM}, \%$ & 55.2 & 56.2 & 69.5 & 68.9 \\
\hline $\mathrm{OM}, \%$ & 91.6 & 92.3 & 91.4 & 91.3 \\
\hline $\mathrm{NE}_{\mathrm{L}}, \mathrm{Mcal} / \mathrm{kg}$ & 1.65 & 1.65 & 1.30 & 1.30 \\
\hline $\mathrm{CP}, \%$ & 17.5 & 12.5 & 17.2 & 12.5 \\
\hline NDF, \% & 43.9 & 43.0 & 51.5 & 50.2 \\
\hline $\mathrm{ADF}, \%$ & 25.3 & 24.4 & 28.7 & 28.2 \\
\hline $\mathrm{Ca}, \%$ & 1.02 & 0.85 & 0.95 & 0.91 \\
\hline $\mathrm{P}, \%$ & 0.44 & 0.40 & 0.45 & 0.44 \\
\hline $\mathrm{K}, \%$ & 1.54 & 1.42 & 1.44 & 1.43 \\
\hline $\mathrm{S}, \%$ & 0.26 & 0.21 & 0.27 & 0.23 \\
\hline $\mathrm{Cl}, \%$ & 0.35 & 0.32 & 0.45 & 0.45 \\
\hline $\mathrm{Mg}, \%$ & 0.35 & 0.32 & 0.35 & 0.35 \\
\hline $\mathrm{Na}, \%$ & 0.18 & 0.16 & 0.17 & 0.17 \\
\hline $\mathrm{Zn}, \mathrm{mg} / \mathrm{kg}$ & 137 & 130 & 110 & 107 \\
\hline $\mathrm{Fe}, \mathrm{mg} / \mathrm{kg}$ & 373 & 284 & 421 & 354 \\
\hline $\mathrm{Mn}, \mathrm{mg} / \mathrm{kg}$ & 136 & 124 & 157 & 151 \\
\hline $\mathrm{Cu}, \mathrm{mg} / \mathrm{kg}$ & 47 & 38 & 37 & 36 \\
\hline DCAD, meq $/ \mathrm{kg}^{5}$ & 211 & 211 & 149 & 165 \\
\hline
\end{tabular}

${ }^{1} \mathrm{HEHP}=$ High energy and high protein, HELP = high energy and low protein, LEHP = low energy and high protein, LELP = low energy and low protein.

${ }^{2}$ Supplemented the diet with $16,760 \mathrm{IU} / \mathrm{kg}$ of vitamin A, $1720 \mathrm{IU} /$ $\mathrm{kg}$ of vitamin $\mathrm{D}$, and $61 \mathrm{IU} / \mathrm{kg}$ of vitamin $\mathrm{E}$.

${ }^{3}$ Supplemented the diet with $0.08 \% \mathrm{Ca}, 0.08 \% \mathrm{P}, 0.14 \% \mathrm{Na}, 0.22$ $\mathrm{mg} / \mathrm{kg}$ of $\mathrm{Co}, 31 \mathrm{mg} / \mathrm{kg}$ of $\mathrm{Cu}, 1.0 \mathrm{mg} / \mathrm{kg}$ of I, $70 \mathrm{mg} / \mathrm{kg}$ of $\mathrm{Mn}, 0.27$ $\mathrm{mg} / \mathrm{kg}$ of Se, $83 \mathrm{mg} / \mathrm{kg}$ of $\mathrm{Zn}$, and $31 \mathrm{mg} / \mathrm{kg}$ of $\mathrm{Fe}$.

${ }^{4}$ Calculated on analysis of individual ingredients. The energy value of grains was based on book values (NRC, 1989) and those of forages on $\mathrm{ADF}$ content.

${ }^{5} \mathrm{DCAD}=$ Dietary cation-anion difference; calculated on analysis of individual ingredients and using the equation $(\mathrm{Na}+\mathrm{K})-(\mathrm{Cl}+\mathrm{S})$.

rolled barley-based concentrate mix on a DM basis. In an attempt to equalize BCS by the time of treatment initiation, cows with a BCS $<3.25$ (scale of 1 to 5 ) were fed additional concentrates (1 to $2.5 \mathrm{~kg} / \mathrm{d}$, depending on BCS). The equalization of BCS continued during the dry period. Cows with a BCS $>3.25$ were fed a faroff dry diet consisting of $16.9 \%$ grass hay, $15.9 \%$ alfalfa silage, $48.7 \%$ barley silage, and $18.5 \%$ concentrate mix 
on a DM basis. Cows with a BCS $<3.25$ continued on the late-lactation diet, but did not continue to receive the additional concentrates. They were switched to the far-off dry diet when they reached BCS 3.25, or at a minimum of $2 \mathrm{wk}$ before starting on the dietary treatments. At the time of treatment initiation, BCS of the cows was 2.96, 3.21, 3.25, and 3.25 for HEHP, HELP, LEHP, and LELP, respectively $(\mathrm{SEM}=0.12)$. Adaptation to the dietary treatments occurred over a 3-d period; each day, the proportion of the experimental diet relative to the far-off dry diet was increased by $25 \%$. Cows were then fed the dietary treatments from $21 \mathrm{~d}$ before expected calving until the day of calving. Due to inherent errors in predicting calving dates, the length of time on treatment ranged from 12 to $31 \mathrm{~d}$, with a mean of $21.3 \pm 1.2(\mathrm{SEM})$. The number of cows on treatment for less than $14 \mathrm{~d}$ was $1,1,0$, and 0 for HEHP, HELP, LEHP, and LELP, respectively. Cows were housed in tie stalls with free access to water, and were exercised daily from $\sim 0930$ to 1030 . All animal procedures were approved by the Faculty of Agriculture, Forestry, and Home Economics Animal Policy and Welfare Committee in accordance with the guidelines of the Canadian Council on Animal Care (1993).

Prepartum, diets were fed ad libitum as a TMR once a day at $\sim 0700 \mathrm{~h}$. After calving, cows were fed a common TMR formulated to meet NRC (1989) recommendations (Table 2). Feed was offered ad libitum once daily at $\sim 0800$. Throughout the trial (21 d before expected calving to 42 DIM), amounts of feed offered were adjusted daily to maintain $10 \%$ orts. Dry matter intake was recorded daily. Chromium oxide $(10 \mathrm{~g} / \mathrm{cow}$ per day) was mixed into the diets as an indigestible marker for estimating total tract digestibility of nutrients.

Moisture content of the silages was determined weekly and used to make ration adjustments. All diet ingredients were sampled weekly and composited biweekly. Samples were dried in a forced-air oven at $60^{\circ} \mathrm{C}$ for $48 \mathrm{~h}$ and ground to pass a $1-\mathrm{mm}$ screen. To determine DM, we dried samples at $100^{\circ} \mathrm{C}$ for $24 \mathrm{~h}$, and we calculated OM as the weight lost upon ashing for a minimum of $6 \mathrm{~h}$ at $550^{\circ} \mathrm{C}$. Orts were sampled twice weekly and composited by week to determine DM. For analytical procedures, orts were composited by cow within period (precalving and postcalving). Ingredients and orts were analyzed for CP (nitrogen $\times$ 6.25) using a Leco FP-428 Nitrogen Determinator (Leco Corporation, St. Joseph, MI). Acid detergent fiber and NDF were determined as described by Van Soest et al. (1991). Mineral content was determined by inductively coupled plasma emission spectroscopy (JY70 plus inductively coupled argon plasma; Jobin
Table 2. Ingredient and nutrient composition of the postpartum diet (DM basis).

\begin{tabular}{lc}
\hline Ingredient composition $(\%)$ & \\
Alfalfa hay & 10.8 \\
Barley silage & 20.8 \\
Alfalfa silage & 17.1 \\
Rolled barley & 25.3 \\
Ground corn & 7.2 \\
Canola meal & 6.3 \\
Soybean meal & 2.1 \\
Corn gluten meal & 2.3 \\
Fishmeal & 2.0 \\
Dry brewers grain & 1.3 \\
Tallow & 2.0 \\
Megalac 1 & 0.5 \\
Molasses & 0.5 \\
Mineral/vitamin premix ${ }^{2}$ & 1.8 \\
Nutrient composition ${ }^{3}$ & \\
DM, \% & 57.7 \\
OM, \% & 91.8 \\
NE, Mcal/kg & 1.73 \\
CP, \% & 17.7 \\
NDF, \% & 38.7 \\
ADF, \% & 20.1 \\
Ca, \% & 1.20 \\
P, \% & 0.48 \\
K, \% & 1.41 \\
S, \% & 0.26 \\
Cl, \% & 0.42 \\
Mg, \% & 0.41 \\
Na, \% & 0.33 \\
Zn, mg/kg & 240 \\
Me, mg/kg & 67 \\
Cu, mg/kg $/ k g$ & 21 \\
Al, mg/kg & 97 \\
B, mg/kg & 14 \\
DCAD, meq/kg & 221 \\
\hline & \\
\hline &
\end{tabular}

${ }^{1}$ Church \& Dwight Co., Inc., Princeton, NJ.

${ }^{2}$ Supplied the diet with $0.27 \% \mathrm{Na}, 0.18 \mathrm{mg} / \mathrm{kg}$ of $\mathrm{Co}, 14 \mathrm{mg} / \mathrm{kg}$ of $\mathrm{Cu}, 0.65 \mathrm{mg} / \mathrm{kg}$ of I, $38 \mathrm{mg} / \mathrm{kg}$ of $\mathrm{Mn}, 0.3 \mathrm{mg} / \mathrm{kg}$ of Se, $40 \mathrm{mg} / \mathrm{kg}$ of $\mathrm{Zn}$, and $30 \mathrm{mg} / \mathrm{kg}$ of $\mathrm{Fe}$.

${ }^{3}$ Calculated on analysis of individual ingredients. The energy value of grains was based on NRC (1989) values and those of forages on ADF content.

${ }^{4}$ DCAD = Dietary cation-anion difference; calculated on analysis of individual ingredients and using the equation $(\mathrm{Na}+\mathrm{K})-(\mathrm{Cl}+\mathrm{S})$.

Yvon, Division d'instruments S. A., Longjumeau, France).

Cows were weighed and body condition scored weekly at $\sim 1030 \mathrm{~h}$ throughout the trial, and on $\mathrm{d} 25$ (pretreatment) before expected calving and d 1 after calving. Energy balance was calculated as the difference between energy consumed and required, where NE required prepartum $=$ maintenance + pregnancy, and NE required postpartum $=$ maintenance + milk. Because this study was completed before the release of the NRC (2001), and formulation of the diets and calculation of the energy content was based on NRC (1989) values, energy requirements are also based on NRC (1989). Energy required for maintenance (Mcal/ d) $=0.08 \times \mathrm{kg}$ of $\mathrm{BW}^{0.75}$ for third-lactation cows and 
$1.1\left(0.08 \times \mathrm{kg} \mathrm{BW}^{0.75}\right)$ for second-lactation cows, $\mathrm{NE}$ for pregnancy $(\mathrm{Mcal} / \mathrm{d})=0.024 \times \mathrm{kg} \mathrm{BW}^{0.75}$, and $\mathrm{NE}$ for lactation $(\mathrm{Mcal} / \mathrm{kg}$ milk $)=0.3512+(0.0962 \times \%$ fat $)$. Crude protein balance was calculated according to NRC (1989). At calving, the calf's sex and weight were determined before colostrum feeding.

Cows were milked at 0600 and $1800 \mathrm{~h}$. Milk yield was electronically recorded for the first $42 \mathrm{~d}$ of lactation. Milk samples, taken twice weekly (Monday p.m./ Tuesday a.m. and Thursday p.m./Friday a.m.) were analyzed for CP, fat, and lactose by infrared analysis at the Alberta Central Milk Testing Laboratory (Edmonton, AB, Canada). Milk samples from wk 2 and 6 were analyzed for fatty acid (FA) composition. Milk fat was extracted and the FA profiles measured by gas chromatography using a Varian model 3700 with a flame-ionization detector (Khorasani et al., 1991).

\section{Sampling and Analysis}

Blood samples were collected via the coccygeal vein at $\sim 4 \mathrm{~h}$ after feeding on two consecutive days before the start of the dietary treatments, once within $24 \mathrm{~h}$ of calving, and weekly from initiation of the trial until 28 DIM. Additional samples were collected at 10, 17, and 24 DIM for progesterone analysis. Blood was collected into evacuated tubes containing sodium heparin, EDTA, potassium oxalate, and sodium fluoride, or no additives. All tubes for plasma collection were immediately placed on ice and centrifuged within 4 h. Samples for serum were allowed to clot at room temperature for at least $4 \mathrm{~h}$ before centrifugation. Samples were centrifuged at $4^{\circ} \mathrm{C}$ for $15 \mathrm{~min}$ at 3300 $\times g$, and stored at $-70^{\circ} \mathrm{C}$ until analysis. Nonesterified fatty acids in serum were determined using the NefaC kit (Wako Chemicals USA Inc., Richmond, VA) with the modifications of Johnson and Peters (1993). Plasma BHBA was determined by the procedure of Williamson and Mellanby (1974) adapted to a 96-well microliter plate format. Plasma glucose was determined using the Beckman Glucose Analyzer 2 (Beckman Instruments, Missisauga, ON). Insulin and IGF1 (Lapierre et al., 2000a) and growth hormone (GH; Lapierre et al., 2000b) were analyzed by double antibody radioimmunoassay. Intra- and interassay coefficients of variation were 9.1 and $6.6 \%,<1$ and $8.4 \%$, and $<1$ and $<1 \%$ for insulin, IGF-1, and GH, respectively. Plasma 3-methylhistidine (3-MH) was determined by HPLC as described by Zurek et al. (1995). Plasma amino acids were quantified by HPLC using the procedure of Sedgwick et al. (1991). Plasma samples were also analyzed for urea nitrogen (PUN; Sigma BUN kit 535, Sigma Chemical Co., St. Louis, MO) and progesterone (Coat-A-Count; Diagnostic Products Corpora- tion, Los Angeles, CA). Cows were considered to have reached first estrus on the first of three consecutive samples with a progesterone concentration greater than $1.0 \mathrm{ng} / \mathrm{ml}$ (Simmons et al., 1994).

Liver samples were obtained by biopsy (Smart, 1985) on d 25 before expected calving, and on d 1 and 21 postpartum. The liver tissue $(\sim 1 \mathrm{~g})$ was rinsed in PBS to remove excess blood and immediately placed in liquid nitrogen. Samples were stored at $-30^{\circ} \mathrm{C}$ until analyzed for TG and glycogen content. Liver lipids were extracted by the method of Folch et al. (1957) and TG content determined by the method of Fletcher (1968) as modified by Foster and Dunn (1973). Liver glycogen was determined by the method of Lo et al. (1970).

Urine samples were collected on $\mathrm{d}-26,-7,10$, and 20 relative to calving. Samples $(500 \mathrm{ml})$ were collected at $1100 \mathrm{~h}$ and stored at $-20^{\circ} \mathrm{C}$ until analyzed for creatinine (Sigma kit 555, Sigma Chemical Co.) and 3-MH as described by Zurek et al. (1995).

To determine nutrient digestibilities, fecal grab samples were obtained twice daily at 12 -h intervals for $6 \mathrm{~d}$ ( $\mathrm{d}-14$ to $\mathrm{d}-9$, and $\mathrm{d} 8$ to $\mathrm{d} 13$ relative to calving). In both the prepartum and postpartum periods, the fecal collection began after the cows were on the chromium oxide-marked feed for $7 \mathrm{~d}$. Each day the samples were obtained $2 \mathrm{~h}$ later than on the previous day. At each collection, $250 \mathrm{~g}$ were kept and composited within period (precalving and postcalving). Samples were stored at $-20^{\circ} \mathrm{C}$ until analyzed. Chromium content in the feces and feed were analyzed by atomic absorption spectrophotometry as described by Fenton and Fenton (1979). Nutrient digestibilities were determined from the ratios of $\mathrm{Cr}$ concentrations in the diet to those in feces. Fecal samples were analyzed for CP, ADF, NDF, and OM using the same methods as those described for the feed ingredients.

Subcutaneous adipose tissue was biopsied from the perianal region on d 25 before expected calving and on $d 1$ and 21 postpartum. Tissue was sampled from the left side on $d 1$, and from the right side on $d-25$ and $\mathrm{d} 21$. The adipose tissue $(\sim 10 \mathrm{~g})$ was rinsed in PBS to remove excess blood, immediately placed in liquid nitrogen, and stored at $-70^{\circ} \mathrm{C}$ until analysis for western blotting and enzyme activity.

Western blotting was performed for acetyl Co-A carboxylase (ACC) and fatty acid synthase (FAS). Homogenization of the adipose tissue $(\sim 1.0 \mathrm{~g})$ and collection of the supernatant was performed as outlined by Moibi et al. (2000). Supernatants were aliquoted and stored at $-70^{\circ} \mathrm{C}$ until analysis. Proteins were quantified with a BCA Protein Assay Reagent kit (Pierce, Rockford, IL). Proteins were separated using SDSPAGE and quantified as described by Beswick and Kennelly (1998). Twenty-five micrograms of protein 
was loaded on the gel. The ACC was detected with streptavidin conjugated to horseradish peroxidase at a concentration of 1:500. The FAS was detected with a primary mouse anti-fatty acid synthase monoclonal antibody and a secondary goat anti-mouse-horseradish-peroxidase. The primary antibody concentration was 1:250 and the secondary antibody was used at a concentration of 1:500.

To measure enzyme activity, 10\% PEG was added to one aliquot and the sample centrifuged at $11,000 \times$ $g$ for $10 \mathrm{~min}$ at $4^{\circ} \mathrm{C}$. The pellet was resuspended in $200 \mu \mathrm{l}$ of resuspension buffer $(100 \mathrm{mM}$ Tris $\mathrm{HCl} \mathrm{pH}$ 7.5, $1 \mathrm{~m} M$ EDTA, $1 \mathrm{~m} M$ EGTA, $50 \mathrm{~m} M$ NaF, $5 \mathrm{~m} M$ $\mathrm{Na}$ pyrophosphate, and $4 \mu \mathrm{g} / \mathrm{ml}$ aprotinin, leupeptin, and pepstatin A) and stored at $-70^{\circ} \mathrm{C}$. The protein content was determined by the bicinchoninic acid method (Pierce, Rockford, IL). The $\mathrm{H}^{14} \mathrm{CO}_{3}^{-}$fixation method as described by Moibi et al. (2000) was used to assay ACC activity. Acetyl-CoA carboxylase activity is expressed as nmol of ${ }^{14} \mathrm{C}$-bicarbonate incorporated into malonyl-CoA $/ \mathrm{min}$ per milligram of protein. The method of Moibi et al. (2000) was used to assay FAS activity. Activity is expressed as nmol NADPH/min per milligram of protein. Lipoprotein lipase (LPL) activity was assayed according to Liesman et al. (1995). Activity is expressed as nmol oleic acid/h per milligram of protein.

\section{Statistical Analysis}

One cow on the HELP treatment aborted before the trial began and one cow on the LEHP treatment calved the day after going on treatment, so 26 cows were used for the trial. One cow on the HELP diet died $2 \mathrm{~d}$ after calving due to calving difficulties, therefore, measurements from the postpartum period were from 25 cows. Dry matter intake data were excluded from one cow on the LELP treatment due to immeasurable feed wastage. One cow on the LELP diet developed right displaced abomasum shortly after parturition, and data during the recovery period (1 wk) was excluded. The cow was successfully treated surgically and continued on the trial. Two cows (one each on HEHP and LELP treatments) developed foot rot after calving that subsequently affected their DMI, so data from the first week postpartum were excluded. Milk compositional data from the first three DIM were excluded for all cows.

Repeated measures data were analyzed using the MIXED procedure of SAS (1999b). The statistical model included block, time, energy, protein, energy $x$ protein interaction, energy $\times$ time interaction, protein $\times$ time interaction, and energy $\times$ protein $\times$ time interaction. For DMI, the periods tested were precalving ve- rusus wk 1 to 3 and wk 4 to 6 postcalving. For milk yield, the periods were wk 1 to 3 and wk 4 to 6 postcalving. For each analyzed variable with equal time spacing between samples, cow nested within energy by protein by block was subjected to three covariance structures: autoregressive order 1, compound symmetry, and spatial power law. For variables with unequal spacing, only compound symmetry and spatial power law covariance structures were used. The covariance structure that resulted in the largest Schwarz's Bayesian criterion and Akaike's information criterion was used. Preplanned comparisons for the effect of time were analyzed by PDIFF (SAS, 1999a). All pretreatment data were statistically analyzed; however, only BW, plasma insulin and IGF-1 concentrations, and ACC, FAS, and LPL protein abundance and activity before the initiation of treatments were significantly different among the different treatments; therefore, pretreatment data for these variables were used as covariates. Single measurement data were analyzed using PROC MIXED with block, energy, protein, and the energy by protein interaction in the model. Progesterone was analyzed as categorical data using PROC FREQ (SAS, 1999a). Correlation coefficients were determined using PROC CORR (SAS, 1999a). In the figures, wk -3 represents data obtained from $d-15$ to $d$ -21 , wk -2 represents data from $\mathrm{d}-8$ to $\mathrm{d}-14$, and wk -1 data are from $d-1$ to $d-7$. Week 0 represents data obtained on the day of calving. Pretreatment values are not shown. Data are reported as least squares

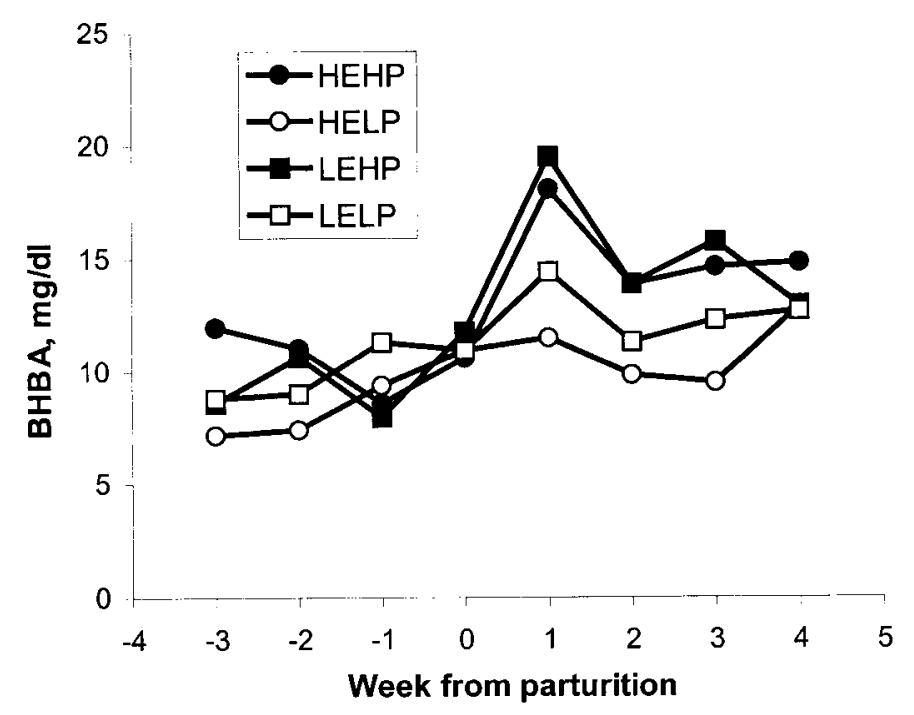

Figure 1. Plasma BHBA concentrations around the time of calving (pooled SEM =1.99). Treatment effects: protein, $P=0.03$. Cows were fed diets for $21 \mathrm{~d}$ before calving that contained a high (HE) or low (LE) concentration of energy and a high (HP) or low (LP) concentration of protein. All cows were fed the same diet postcalving. The data for calving (wk 0) were obtained within $24 \mathrm{~h}$ of calving. 


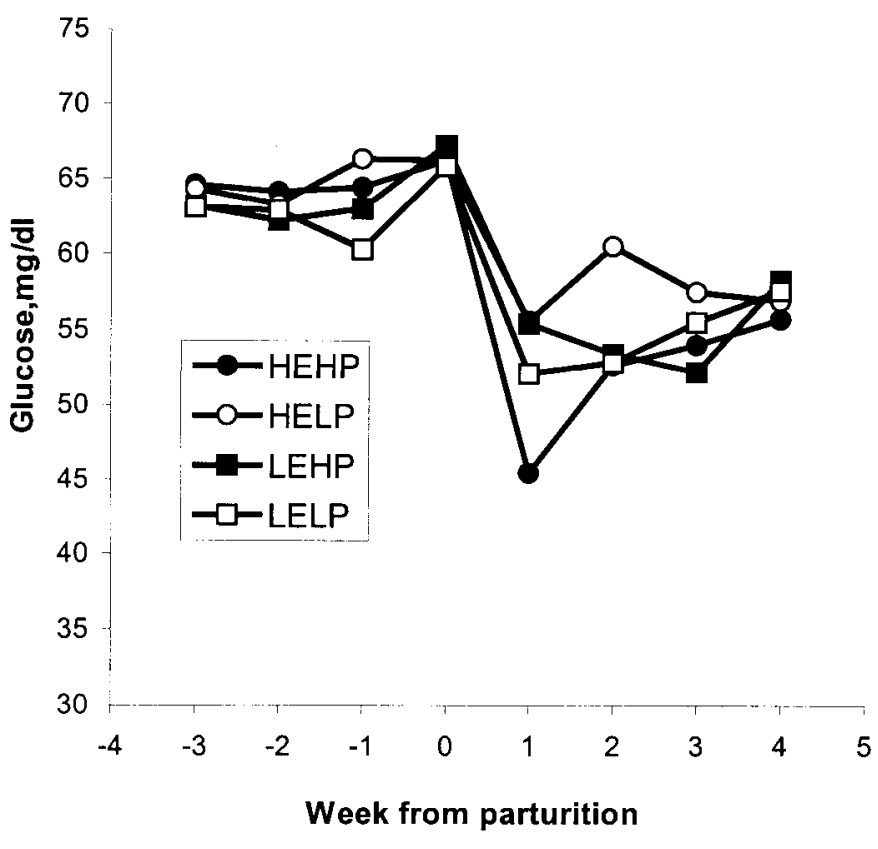

Figure 2. Plasma glucose concentrations around the time of calving (pooled SEM $=2.75)$. There were no treatment effects $(P>0.05)$. Cows were fed diets for $21 \mathrm{~d}$ before calving that contained a high (HE) or low (LE) concentration of energy and a high (HP) or low (LP) concentration of protein. All cows were fed the same diet postcalving. The data for calving (wk 0) were obtained within $24 \mathrm{~h}$ of calving.

means with pooled standard errors. Significance was declared at $P<0.05$.

\section{RESULTS}

\section{Metabolic Parameters}

Dietary protein had a significant effect on BHBA concentrations (12.8 vs. $10.6 \mathrm{mg} / \mathrm{dl}$ for HP and LP; $P$ $=0.03$; Figure 1 ); however, this effect was evident only in the postpartum period, primarily at wk 1 (protein $\times$ week interaction, $P=0.10$ ). Time also influenced BHBA concentrations, with levels being higher postpartum than prepartum $(P<0.001)$. Across all time points, glucose was unaffected by prepartum treatment (Figure 2). As with BHBA, the effect of time was significant $(P<0.001)$; glucose concentrations were lower postcalving than precalving.

Plasma insulin concentrations declined steadily from wk -3 to calving and then remained at low levels postpartum (Figure 3). There was a tendency for an energy $\times$ protein interaction $(P=0.06)$. When $\mathrm{HE}$ was associated with HP, insulin was higher than it was when associated with LP. The reverse was true for LE; insulin concentrations were higher when LE was associated with LP. The concentrations of IGF-1 over time followed the same general pattern as for insulin

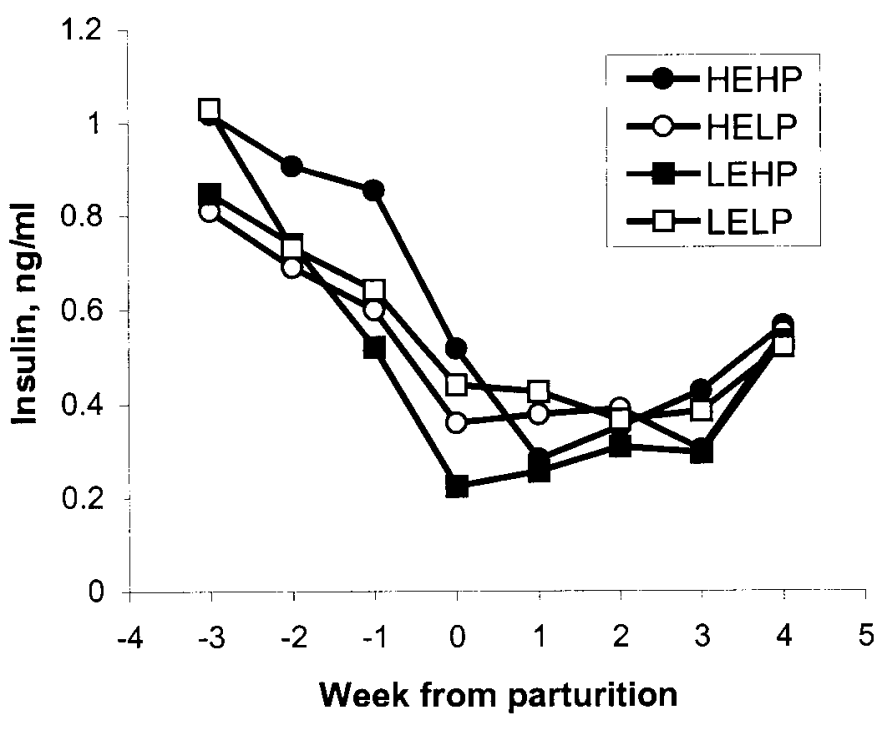

Figure 3. Plasma insulin concentrations around the time of calving (pooled $\mathrm{SEM}=0.09$ ). Treatment effect: energy $\times$ protein, $P=0.06$. Cows were fed diets for $21 \mathrm{~d}$ before calving that contained a high (HE) or low (LE) concentration of energy and a high (HP) or low (LP) concentration of protein. All cows were fed the same diet postcalving. Data were covariately adjusted for differences in pretreatment values. The data for calving (wk 0 ) were obtained within $24 \mathrm{~h}$ of calving.

(Figure 4); however, there were no treatment effects. From wk -3 to -1 , plasma GH concentrations were relatively stable and then increased rapidly $(P<0.001)$

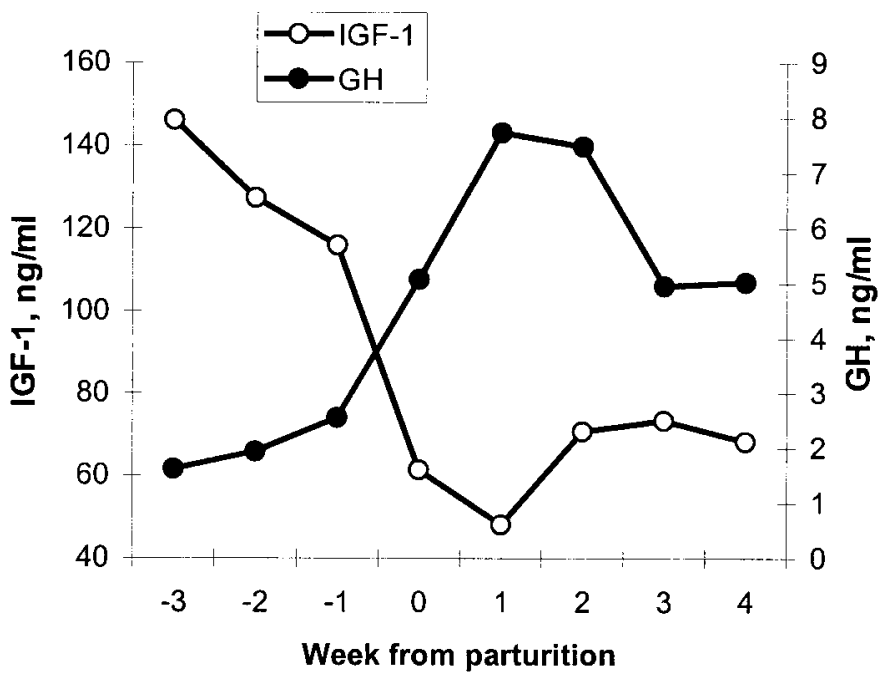

Figure 4. Plasma IGF-1 (pooled SEM = 8.60) and growth hormone $(\mathrm{GH})$ concentrations (pooled $\mathrm{SEM}=1.23$ ) around the time of calving. There were no treatment effects $(P>0.10)$. Cows were fed diets for $21 \mathrm{~d}$ before calving that contained a high (HE) or low (LE) concentration of energy and a high (HP) or low (LP) concentration of protein. All cows were fed the same diet postcalving. Data were covariately adjusted for differences in pretreatment values. The data for calving (wk 0 ) were obtained within $24 \mathrm{~h}$ of calving. 


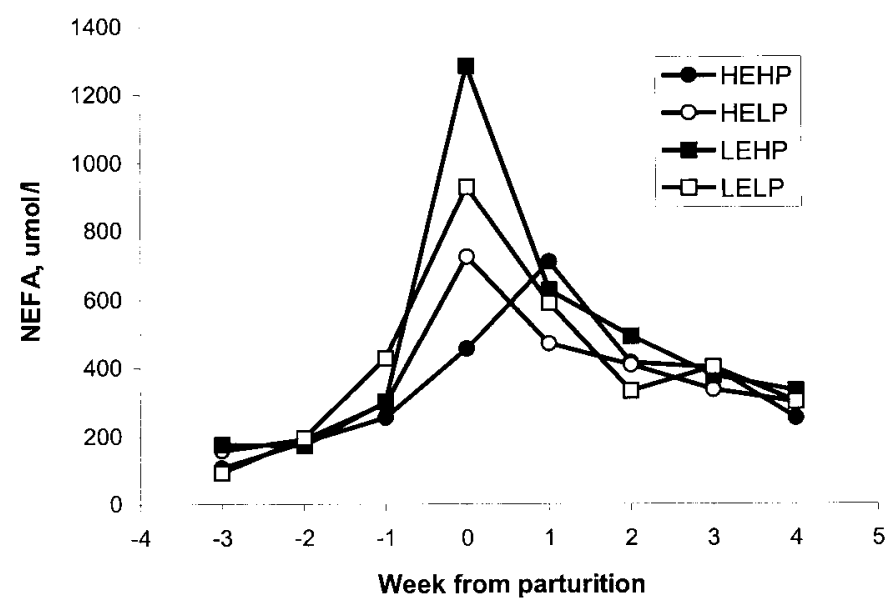

Figure 5. Plasma NEFA concentrations around the time of calving (pooled SEM = 93.7). Treatment effects: energy $\times$ week, $P<0.001$; energy $\times$ protein $\times$ week, $P=0.005$. Cows were fed diets for $21 \mathrm{~d}$ before calving that contained a high (HE) or low (LE) concentration of energy and a high (HP) or low (LP) concentration of protein. All cows were fed the same diet postcalving. The data for calving (wk 0 ) were obtained within $24 \mathrm{~h}$ of calving.

as calving approached (Figure 4). Concentrations peaked at $1 \mathrm{wk}$ postcalving and declined thereafter. There were no treatment effects either prepartum or postpartum.

\section{Lipid Metabolism}

There was an energy $\times$ protein by week interaction for plasma NEFA $(P=0.005$; Figure 5$)$. Concentrations of NEFA were low in the prepartum period (214.9 \pm $32.1 \mu \mathrm{mol} / \mathrm{L}$ ) and peaked at calving for all dietary treatments except HEHP, which peaked at $1 \mathrm{wk}$ postcalving. Cows fed LEHP had the highest NEFA levels at calving (1286.1 $\pm 90.2 \mu \mathrm{mol} / \mathrm{L})$. Postcalving, the concentration of NEFA declined as DIM increased and was not different among the treatments, averaging $422.0 \pm 27.2 \mu \mathrm{mol} / \mathrm{L}$. There was an energy $\times$ week interaction $(P<0.001)$; at calving, cows fed the LE diets had higher NEFA concentrations than cows on the HE diets, but at other time points, there were no differences between the two groups. There was a negative correlation between the change in NEFA from $d-7$ to calving and the change in DMI during the same time period ( $\mathrm{r}=-0.59, P=0.002)$. Because reductions in DMI lead to reductions in energy balance, there was also a negative correlation between NEFA concentrations and energy balance during the last week prepartum $(\mathrm{r}=-0.72, P<0.001)$ and at calving $(\mathrm{r}=-0.60, P$ $=0.002)$.

Liver TG content increased approximately fivefold from $25 \mathrm{~d}$ precalving to the day of calving, and another
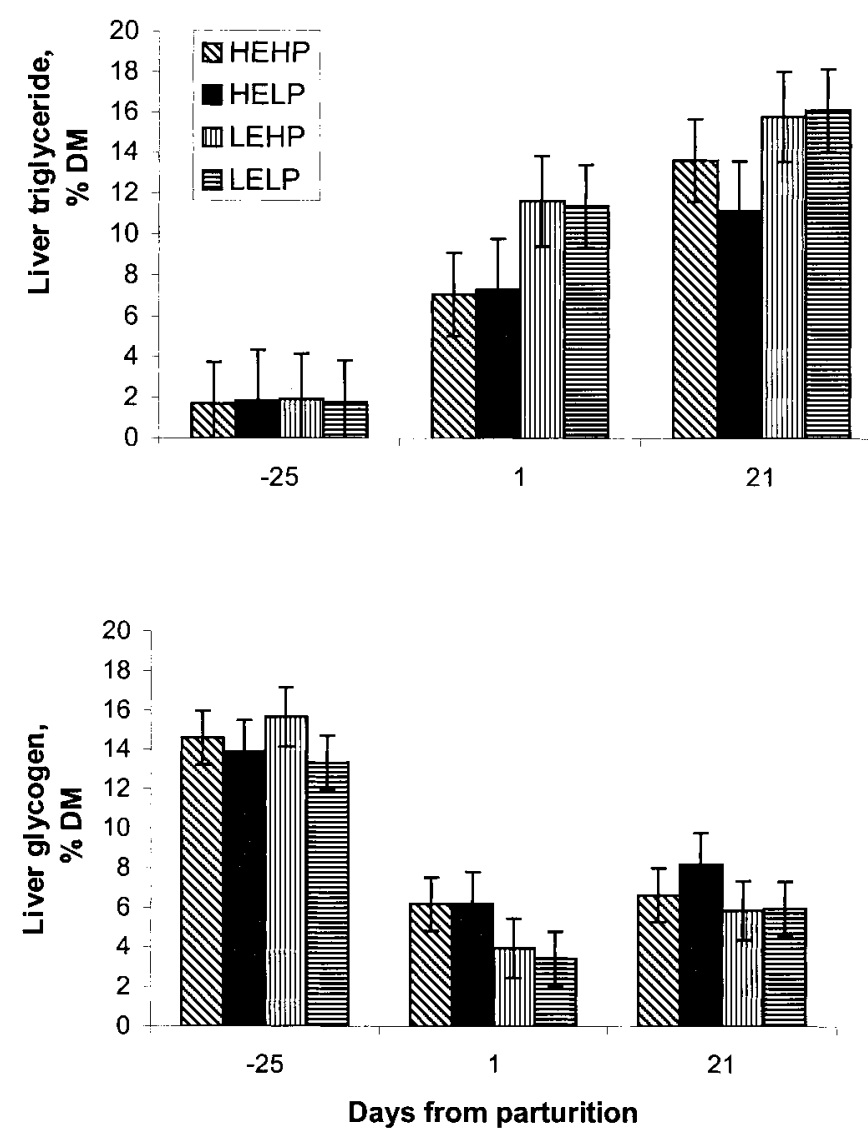

Figure 6. Concentrations of liver triglyceride (upper panel; pooled SEM = 2.17) and glycogen (lower panel; pooled SEM = 1.44; $(\mathrm{DM}$ basis) of cows during the transition period. Treatment effects for liver triglyceride: energy, $P=0.06$. There were no treatment effects on liver glycogen $(P>0.05)$. Cows were fed diets for $21 \mathrm{~d}$ before calving that contained a high (HE) or low (LE) concentration of energy and a high (HP) or low (LP) concentration of protein. All cows were fed the same diet postcalving. Day -25 data are pretreatment.

1.5 fold from calving to $21 \mathrm{~d}$ postcalving (time effect, $P<0.001$; Figure 6). Energy content of the diet had a significant effect on TG concentrations, which averaged $7.1 \%$ for $\mathrm{HE}$ and $9.8 \%$ for $\mathrm{LE}(P=0.06)$. There was a negative correlation between liver TG and energy balance on the day of calving $(\mathrm{r}=-0.50, P=0.01)$. Liver glycogen content was $14.4 \%$ at $d-25$, declined to $4.9 \%$ on $\mathrm{d} 1$, and then increased to $6.7 \%$ on $\mathrm{d} 21$ (time effect, $P<0.001$; Figure 6). Prepartum treatment had no effect on hepatic glycogen content. There was a negative relationship between liver TG and glycogen content $(\mathrm{r}=-0.70, P<0.001)$.

Western blot analysis of the adipose tissue revealed that there was an effect of treatment on the abundance of the ACC protein (Table 3, Figure 7). Acetyl-CoA carboxylase abundance was higher with the HE treatments on 1 postcalving than with the LE treatments, but was the same on $d 21$ (energy $\times$ day interaction, 
Table 3. Adipose tissue acetyl-CoA carboxylase and fatty acid synthase abundance around the time of calving. ${ }^{1}$

\begin{tabular}{|c|c|c|c|c|c|c|c|c|c|c|c|}
\hline & \multicolumn{4}{|c|}{ Treatment $^{2}$} & \multirow[b]{2}{*}{ SEM } & \multicolumn{6}{|c|}{$P^{3}$} \\
\hline & HEHP & HELP & LEHP & LELP & & $\mathrm{D}$ & $\mathrm{E}$ & $\mathrm{P}$ & $\mathrm{E} \times \mathrm{P}$ & $\mathrm{E} \times \mathrm{D}$ & $\mathrm{P} \times \mathrm{D}$ \\
\hline $\begin{array}{c}\text { Acetyl-CoA carboxylase }{ }^{4} \\
\mathrm{~d}-25(\text { covariate period })\end{array}$ & 1.68 & & & & 0.20 & & & & & & \\
\hline d 1 & 0.95 & 1.15 & 0.63 & 0.73 & 0.14 & 0.001 & 0.32 & 0.88 & 0.90 & 0.005 & 0.10 \\
\hline d 21 & 0.35 & 0.16 & 0.37 & 0.35 & 0.15 & & & & & & \\
\hline $\begin{array}{l}\text { Fatty acid synthase }{ }^{4} \\
\text { d }-25 \text { (covariate period) }\end{array}$ & 1.32 & & & & 0.17 & & & & & & \\
\hline d 1 & 0.73 & 1.18 & 0.51 & 0.51 & 0.15 & 0.001 & 0.20 & 0.53 & 0.28 & 0.006 & 0.11 \\
\hline d 21 & 0.06 & 0.05 & 0.22 & 0.08 & 0.16 & & & & & & \\
\hline
\end{tabular}

${ }^{1} \mathrm{LS}$ means are presented with the pooled standard error of the mean (SEM).

${ }^{2} \mathrm{HEHP}=$ High energy and high protein, HELP = high energy and low protein, LEHP = low energy and high protein, LELP = low energy and low protein.

${ }^{3} P$-value for treatment and time effects: $\mathrm{E}=$ energy, $P=$ protein, $\mathrm{D}=$ day; the $P$-values for $\mathrm{E}$ and $\mathrm{P}$ represent the overall significance across $\mathrm{d} 1$ and $\mathrm{d} 21$.

${ }^{4}$ Data for $\mathrm{d}-25$ are pooled because cows were not on treatment; data for $\mathrm{d} 1$ and 21 were covariately adjusted for differences in pretreatment values; data is expressed as densitometric units/25 $\mu \mathrm{g}$ cytosolic protein.

$P=0.002)$. There was also an energy $\times$ day effect on the abundance of FAS $(P=0.006)$. On $d 1$, the FAS abundance in adipose tissue averaged $0.95 \mathrm{OD} \times \mathrm{mm}^{2}$ in cows on the HE treatments and was significantly higher than the abundance in cows on the LE treatment, which was $0.51 \mathrm{OD} \times \mathrm{mm}^{2}$. On $\mathrm{d} 21$ there were no differences between the two treatments. The effect of time was significant $(P<0.001)$ for both ACC and FAS, with values being lower on $d 21$ than $d 1$. Prepartum dietary treatment had no effect on ACC activity on $\mathrm{d} 1$ or $\mathrm{d} 21$ postcalving (Table 4). As with ACC abundance, the effect of time was significant $(P=0.05)$ for ACC activity. Fatty acid synthase activity was not influenced by treatment, but did decline from $d 1$ to
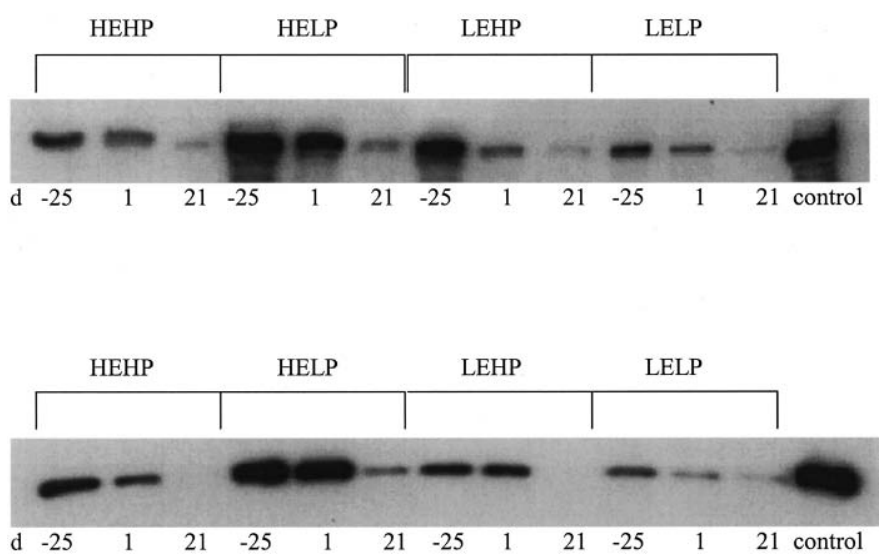

Figure 7. Western blot of acetyl-CoA-carboxylase protein (265 $\mathrm{kDa}$, upper panel) and FAS protein $(260 \mathrm{kDa}$, lower panel) in adipose tissue. Each treatment within a block was represented on the same gel. Data from one cow is represented for each treatment. Cows were fed diets for $21 \mathrm{~d}$ before calving that contained a high (HE) or low (LE) concentration of energy and a high (HP) or low (LP) concentration of protein. All cows were fed the same diet postcalving.
21 (time effect, $P=0.06$ ). Only time was a significant factor on the activity of lipoprotein lipase, with the activity decreasing $(P=0.004)$ as lactation progressed.

\section{Protein Metabolism}

In the precalving period, PUN was higher for the HP treatments than LP (15.9 vs. $11.5 \mathrm{mg} / \mathrm{dl})$, but this effect disappeared postcalving (protein $\times$ time effect, $P=0.003$; Figure 8 ). There was also a protein $\times$ energy interaction $(P=0.05)$. When $\mathrm{HE}$ was associated with HP, PUN was higher than when HE was associated with LP (16.8 vs. $13.3 \mathrm{mg} / \mathrm{dl})$. However, PUN was similar on the LE diets regardless of dietary protein level $(14.3 \mathrm{mg} / \mathrm{dl}$ for LEHP vs. $13.7 \mathrm{mg} / \mathrm{dl}$ for LELP). A protein $\times$ time interaction also existed for plasma $3-\mathrm{MH}$. 3-methylhistidine was higher precalving for cows fed LP compared to those fed HP ( $P=0.004$; Figure 9). The concentration of 3-MH peaked at calving for cows on the LP treatment, whereas it peaked at 1 wk postcalving for cows on the HP treatment. In the postpartum period, there was no effect of treatment on 3-MH.

Plasma AA concentrations are shown in Table 5. Because there were no treatment effects for the majority of the AA, data are pooled and presented by day of sampling only. With the exception of His, Met, and Phe, all of the essential amino acid (EAA) concentrations decreased at calving $(P<0.001)$. Relative to $\mathrm{d} 1$, the concentrations at d 21 were higher for Arg, Ile, Lys, Thr, and Trp, lower for His and Phe, and unchanged for Leu, Val, and Met. Arginine, Ile, Trp, Met, Lys, Phe, and Thr were unaffected by treatment. Over the course of the trial, histidine concentrations were affected by energy content of the diet $(50.5 \mu \mathrm{mol} / \mathrm{L}$ vs. $55.5 \mu \mathrm{mol} /$ $\mathrm{L}$ for $\mathrm{HE}$ and $\mathrm{LE}$, respectively, $P=0.03$ ). Leucine concentrations were increased by the HP $\operatorname{diet}(130.9 \mu \mathrm{mol} /$ 
Table 4. Adipose tissue acetyl-CoA carboxylase, fatty acid synthase, and lipoprotein lipase activity around the time of calving. ${ }^{1}$

\begin{tabular}{|c|c|c|c|c|c|c|c|c|c|c|c|}
\hline & \multicolumn{4}{|c|}{ Treatment ${ }^{2}$} & \multirow[b]{2}{*}{ SEM } & \multicolumn{6}{|c|}{$P^{3}$} \\
\hline & HEHP & HELP & LEHP & LELP & & $\mathrm{D}$ & $\mathrm{E}$ & $\mathrm{P}$ & $\mathrm{E} \times \mathrm{P}$ & $\mathrm{E} \times \mathrm{D}$ & $\mathrm{P} \times \mathrm{D}$ \\
\hline \multicolumn{12}{|l|}{ Acetyl-CoA carboxylase $e^{4,5}$} \\
\hline d 1 & 1.97 & 1.77 & 1.58 & 2.45 & 0.80 & 0.05 & 0.95 & 0.77 & 0.61 & 0.86 & 0.38 \\
\hline $\mathrm{d} 21$ & 1.14 & 0.41 & 1.03 & 0.40 & 0.82 & & & & & & \\
\hline \multicolumn{12}{|l|}{ Fatty acid synthase $e^{4,6}$} \\
\hline $\mathrm{d}-25$ (covariate period) & 265.5 & & & & 53.5 & & & & & & \\
\hline \multicolumn{12}{|l|}{ Lipoprotein lipase $^{4,7}$} \\
\hline $\mathrm{d}-25$ covariate period) & 498.8 & & & & 138.7 & & & & & & \\
\hline $\mathrm{d} 1$ & 247.2 & 453.6 & 427.4 & 537.3 & 110.3 & 0.004 & 0.56 & 0.26 & 0.61 & 0.28 & 0.48 \\
\hline $\mathrm{d} 21$ & 146.6 & 249.1 & 167.8 & 179.6 & 119.3 & & & & & & \\
\hline
\end{tabular}

${ }^{1} \mathrm{LS}$ means are presented with the pooled standard error of the mean (SEM).

${ }^{2} \mathrm{HEHP}=$ High energy and high protein, HELP = high energy and low protein, LEHP = low energy and high protein, LELP = low energy and low protein.

${ }^{3} P$-value for treatment and time effects: $\mathrm{E}=$ energy, $P=$ protein, $\mathrm{D}=$ day; the $P$-values for $\mathrm{E}$ and $\mathrm{P}$ represent the overall significance across $d 1$ and $d 21$.

${ }^{4}$ Data for $d-25$ are pooled because cows were not on treatments; data for $d 1$ and 21 were covariately adjusted for differences in pretreatment values.

${ }^{5}$ Activity is expressed as nmol $\mathrm{H}^{14} \mathrm{CO}_{3}$ incorporated into malonyl-CoA/min per mg protein.

${ }^{6}$ Activity is expressed as nmol NADPH/min per mg protein.

${ }^{7}$ Activity is expressed as nmol oleic acid/h per mg protein.

$\mathrm{L}$ and $108.8 \mu \mathrm{mol} / \mathrm{L}$ for HP and LP, respectively). Valine concentrations were also influenced by the protein content of the $\operatorname{diet}(P=0.02)$, and were higher for the HP treatments $(198.2 \mu \mathrm{mol} / \mathrm{L})$ than the LP treatments $(172.1 \mu \mathrm{mol} / \mathrm{L})$. The majority of the nonessential AA

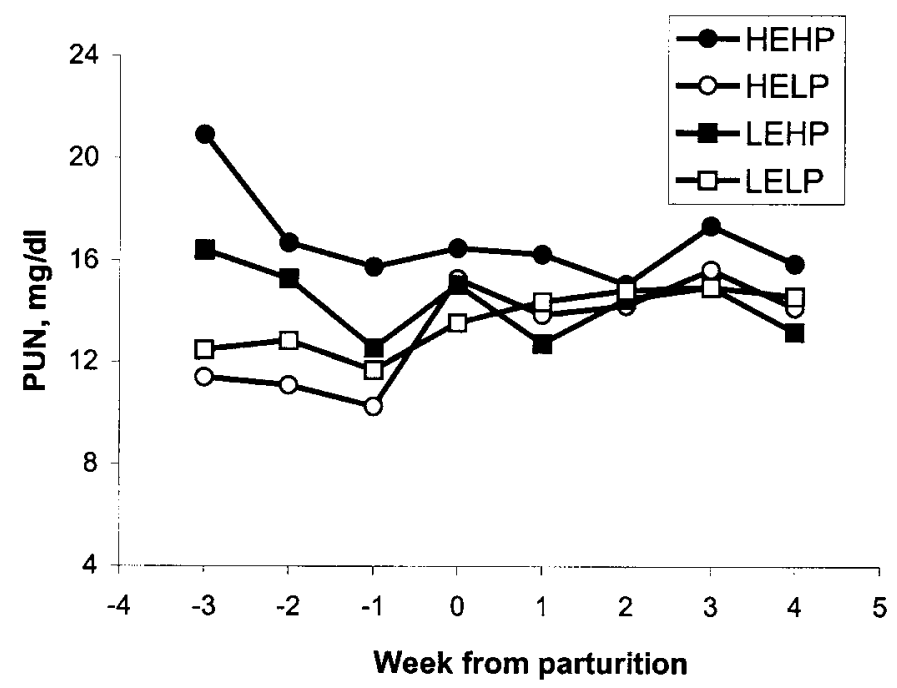

Figure 8. Plasma urea nitrogen (PUN) concentrations around the time of calving (pooled SEM $=1.18$ ). Treatment effects: protein $\times$ energy, $P=0.05$; protein $\times$ week, $P=0.003$. Cows were fed diets for $21 \mathrm{~d}$ before calving that contained a high (HE) or low (LE) concentration of energy and a high (HP) or low (LP) concentration of protein. All cows were fed the same diet postcalving. The data for calving (wk 0 ) were obtained within $24 \mathrm{~h}$ of calving.
(NEAA) were unaffected by diet. Glutamine and Gly concentrations rose sharply between $d-7$ and $d-2$. At calving, the concentration of Glu rose and the concentrations of Ala and Ser were unchanged. The other

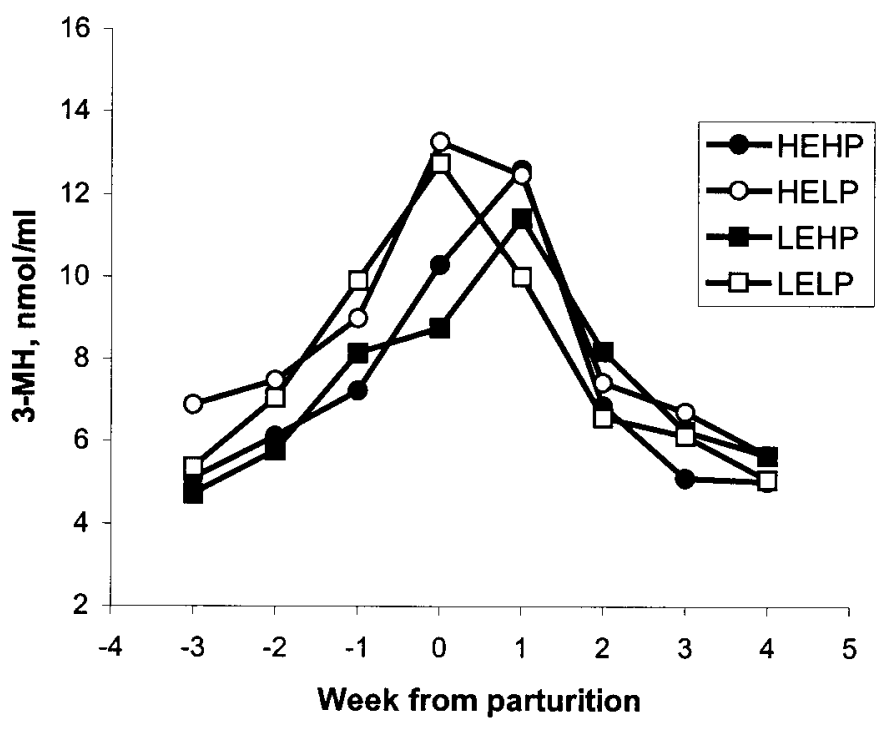

Figure 9. Plasma 3-methylhistidine (3-MH) concentrations around the time of calving (pooled SEM = 1.18). Treatment effect: protein $\times$ week, $P=0.004$. Cows were fed diets for $21 \mathrm{~d}$ before calving that contained a high (HE) or low (LE) concentration of energy and a high (HP) or low (LP) concentration of protein. All cows were fed the same diet postcalving. The data for calving (wk 0 ) were obtained within $24 \mathrm{~h}$ of calving. 
DOEPEL ET AL.

Table 5. Plasma amino acid concentrations $(\mu \mathrm{M})$ around the time of calving. ${ }^{1}$

\begin{tabular}{|c|c|c|c|c|c|c|c|c|}
\hline & \multicolumn{5}{|c|}{ Day } & \multirow[b]{2}{*}{ SEM } & \multicolumn{2}{|c|}{$P^{2}$} \\
\hline & $-25^{3}$ & -7 & -2 & 1 & 21 & & -2 vs 1 & 1 vs 21 \\
\hline \multicolumn{9}{|c|}{ Essential amino acids } \\
\hline Arg & 77.4 & 81.5 & 77.4 & 57.2 & 68.0 & 3.1 & 0.001 & 0.01 \\
\hline His & 53.5 & 61.4 & 56.8 & 52.4 & 40.9 & 2.3 & 0.15 & 0.001 \\
\hline Ile & 92.5 & 104.3 & 100.7 & 69.8 & 87.1 & 3.7 & 0.001 & 0.001 \\
\hline Leu & 105.9 & 145.0 & 137.7 & 101.3 & 109.4 & 6.7 & 0.001 & 0.39 \\
\hline Lys & 71.6 & 75.6 & 66.1 & 49.7 & 63.4 & 3.3 & 0.001 & 0.001 \\
\hline Met & 22.3 & 20.1 & 18.8 & 19.3 & 18.8 & 0.8 & 0.47 & 0.64 \\
\hline Phe & 43.0 & 51.5 & 45.5 & 42.2 & 37.9 & 1.5 & 0.07 & 0.01 \\
\hline Thr & 75.6 & 67.9 & 56.1 & 46.2 & 60.8 & 3.0 & 0.001 & 0.001 \\
\hline Trp & 33.9 & 30.0 & 24.2 & 14.6 & 28.3 & 1.4 & 0.001 & 0.001 \\
\hline Val & 187.8 & 228.8 & 208.2 & 140.1 & 160.8 & 10.6 & 0.001 & 0.16 \\
\hline \multicolumn{9}{|c|}{ Nonessential amino acids } \\
\hline Ala & 164.8 & 136.4 & 148.4 & 152.6 & 153.5 & 8.3 & 0.61 & 0.94 \\
\hline Asn & 27.7 & 32.5 & 35.8 & 23.2 & 33.8 & 1.2 & 0.001 & 0.001 \\
\hline Asp & 7.6 & 8.3 & 8.2 & 5.9 & 8.8 & 0.4 & 0.001 & 0.001 \\
\hline Cit & 59.6 & 71.4 & 74.8 & 57.5 & 73.5 & 2.4 & 0.001 & 0.001 \\
\hline Gln & 254.8 & 237.6 & 306.8 & 217.6 & 189.1 & 9.4 & 0.001 & 0.03 \\
\hline Glu & 98.9 & 80.8 & 52.6 & 81.4 & 101.9 & 6.4 & 0.002 & 0.02 \\
\hline Gly & 143.4 & 162.2 & 272.6 & 208.6 & 233.7 & 13.8 & 0.001 & 0.19 \\
\hline Orn & 42.8 & 45.2 & 36.9 & 29.9 & 36.4 & 1.8 & 0.005 & 0.004 \\
\hline Ser & 56.3 & 65.2 & 67.7 & 65.0 & 64.6 & 3.0 & 0.47 & 0.93 \\
\hline Tyr & 47.9 & 50.8 & 37.4 & 34.1 & 42.3 & 1.8 & 0.05 & 0.001 \\
\hline
\end{tabular}

${ }^{1} \mathrm{LS}$ means are presented with the pooled standard error of the mean (SEM).

${ }^{2} P$-value for day.

${ }^{3} \mathrm{~d}-25$ values are pretreatment.

NEAA experienced a drop at calving. With the exception of Gln, which was lower, and Ala, Gly, and Ser, which were unchanged, concentrations of the NEAA were higher on $\mathrm{d} 21$ postcalving than on $\mathrm{d} 1$.

Across all time points, urinary creatinine concentration was unaffected by treatment. Average values were $97.7,141.1,97.3$, and $77.8 \mathrm{mg} / \mathrm{dl}$ on $\mathrm{d}-25,-7,10$, and 20 relative to calving, respectively. Average creatinine concentrations were lower $(P<0.001)$ postpartum than during the prepartum treatment period. The 3$\mathrm{MH}$ :creatinine ratio increased from $\mathrm{d}-25$ to -7 , and was subject to an energy $\times$ time interaction $(P=0.1$; Figure 10). On $d-25,-7$, and 10 there were no treatment differences, but on $d 20$, the ratio was higher for cows fed the HE diets compared to those fed LE.

\section{DMI, BW, BCS, and Energy and Protein Balance}

Prepartum DMI decreased as calving approached, and averaged $13.8 \mathrm{~kg}$ at $3 \mathrm{wk}$ prepartum and $7.6 \mathrm{~kg}$ on the day of calving (Figure 11). The reduction in DMI from $d-7$ to the day of calving was 26.5, 33.4, 60.0, and $35.1 \%$ for HEHP, HELP, LEHP, and LELP, respectively. The reduction of the LEHP treatment was greater $(P<0.05)$ than that of the other treatments. There was an energy $\times$ period interaction on DMI $(P=0.01)$. During the precalving period, DMI of
HE cows was the same as LE cows, but during the postcalving period, intake was higher for HE than LE (Table 6). The same interaction existed for DMI as a percentage of $\mathrm{BW}(P<0.01$; data not shown $)$. A protein $\times$ period interaction $(P<0.001)$ indicated that prepartum CP intake was higher for HP than LP (2.68 vs. $2.19 \pm 0.09 \mathrm{~kg} / \mathrm{d}$ ), but postpartum CP intake was not

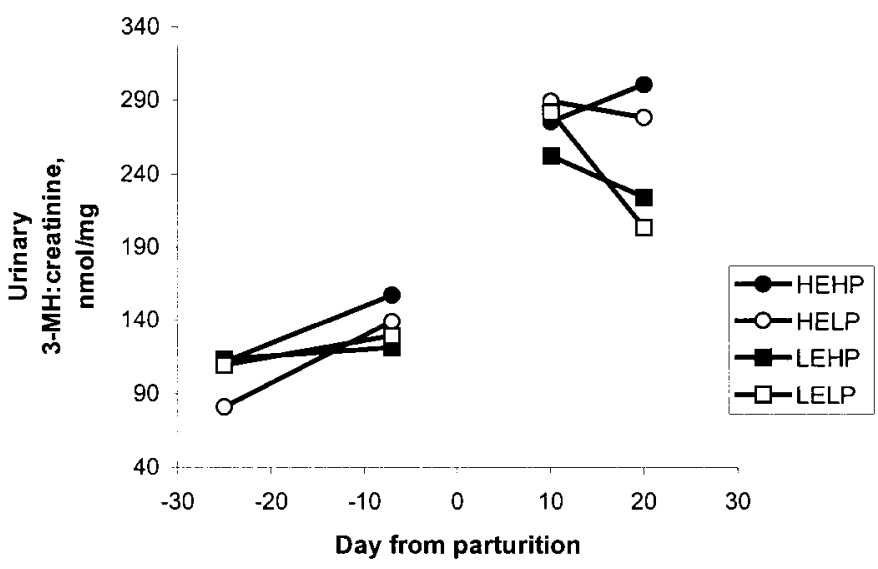

Figure 10. Urinary 3-methylhistidine (3-MH):creatinine ratio (pooled SEM $=26.8$ ) around the time of calving. Treatment effect: energy $\times$ day, $P=0.1$. Cows were fed diets for $21 \mathrm{~d}$ before calving that contained a high (HE) or low (LE) concentration of energy and a high (HP) or low (LP) concentration of protein. All cows were fed the same diet postcalving. Day -25 data are pretreatment. 
different between the two treatments. During both the prepartum and postpartum periods, net energy intake was higher $(P=0.01)$ for cows fed HE compared to those fed LE (prepartum: 20.7 vs. $17.2 \pm 1.0 \mathrm{Mcal} / \mathrm{d}$; postpartum: 30.4 vs. $26.8 \pm 1.0 \mathrm{Mcal} / \mathrm{d}$ ).

Prepartum, cows were in positive energy balance until the immediate precalving period, entering a period of negative energy balance at $d 1,-1,-3$, and -2 for HEHP, HELP, LEHP, and LELP, respectively (Figure 12). Cows on the LEHP treatment experienced the largest drop in DMI at calving and, therefore, were in the most negative energy balance. After calving, cows on all four treatments were in negative energy balance, reaching a nadir at wk 1 postpartum. Across all weeks, cows on HE were in better $(P=0.003)$ energy balance than cows on LE. Crude protein balance was affected by treatment (protein $\times$ week interaction, $P<$ 0.001; Figure 12). During the prepartum period, cows on the HP treatments were in significantly greater protein balance than cows on LP, while there was no difference between the two groups postpartum.

Prepartum BW and BW changes were not affected by treatment (Figure 13, Table 6 ). There was also no effect of treatment on postpartum BW and BW change. Cows lost on average $55.2 \pm 9.6 \mathrm{~kg}$ during the first 42 DIM. Body condition score and BCS changes in the prepartum and postpartum periods were unaffected by treatment (Table 6 ). Over the first 42 DIM, all cows

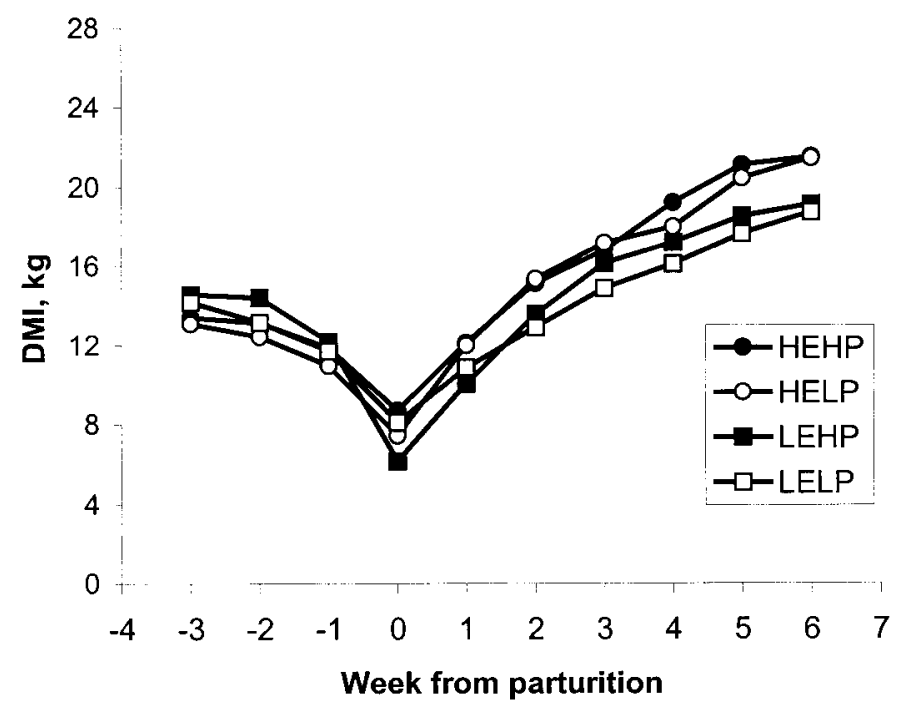

Figure 11. Daily DMI (pooled SEM = 1.04). Treatment effects: energy $\times$ period, $P<0.01$. Cows were fed diets for $21 \mathrm{~d}$ before calving that contained a high (HE) or low (LE) concentration of energy and a high (HP) or low (LP) concentration of protein. All cows were fed the same diet postcalving. The data for week, with the exception of wk 0 , represent the average of $7 \mathrm{~d}$. The data for wk 0 were obtained from the day of calving only. lost condition, with the average loss being $0.54 \pm$ 0.09 units.

Average calf weight at birth $(44.8 \pm 1.6 \mathrm{~kg})$ was unaffected by treatment. The incidence of metabolic disorders was relatively low. One cow fed HEHP developed mastitis, one cow on the HELP treatment had dystocia and subsequently died, two cows fed LEHP experienced retained placenta, and one cow on the LELP treatment had a right displaced abomasum. Prepartum treatment had no effect on day to first estrus as measured by plasma progesterone concentration. Eleven of the 25 cows reached first estrus by $28 \mathrm{~d}$ postpartum.

\section{Milk Yield and Composition}

Treatment had no effect on milk yield during the first 42 DIM (Table 6, Figure 14). Because of difficulties with the adipose tissue biopsies at $\mathrm{d} 21$ that subsequently affected DMI and milk yield, milk yield and composition were analyzed separately for the two 3 -wk periods following calving. Milk yield averaged $32.3 \pm 1.9 \mathrm{~kg} / \mathrm{d}$ during the first $21 \mathrm{DIM}$, and $40.2 \pm 2.0 \mathrm{~kg} / \mathrm{d}$ during d 22 to 42 . Although cows fed the HE diets produced over $2 \mathrm{~kg}$ more milk per day than cows on the LE diets during the first 21 DIM, this difference was not statistically significant $(P=0.22)$, likely due to inadequate replication. Completion of this study with a greater number of cows may have allowed detection of differences in performance. Milk fat, protein, and lactose yields were unaffected by diet (Table 6). Milk fat content during the first $3 \mathrm{wk}$ postpartum tended to be lower with the HE diets than the LE diets, but was not different during wk 4 to 6 (energy $\times$ period interaction, $P=0.08$ ). There was no effect of treatment on milk protein content. Milk FA composition at wk 2 and 6 was also unaffected by treatment, therefore, average data are presented in Table 7. There was a time effect $(P<0.05)$ for all the FA except $\mathrm{C} 4: 0, \mathrm{C} 16: 0, \mathrm{C} 18: 3, \mathrm{C} 20: 0$, and C22:1. At wk 2, the concentration of short chain FA was lower $(P<0.001)$ than at wk 6 , while the long-chain FA had higher concentrations $(P<0.001)$ at wk 2 compared with wk 6 .

\section{Nutrient Digestibility}

Whole tract apparent nutrient digestibility is shown in Table 8. Prepartum DM $(P=0.002)$ and OM digestibility was higher $(P<0.01)$ for the HE diets than the LE diets (DM: 69.3 vs. $64.0 \%$; OM: 72.6 vs. $66.8 \%$ ). Crude protein digestibility was affected by dietary protein level $(P=0.001)$, averaging $69.6 \%$ for the HP treatments and $61.2 \%$ for LP. Neither energy nor protein content of the dietary treatments affected prepartum ADF digestibility, but there was an energy $\times$ protein interaction $(P=$ 
Table 6. Effect of prepartum dietary treatment on lactation performance and change in BW and BCS. ${ }^{1}$

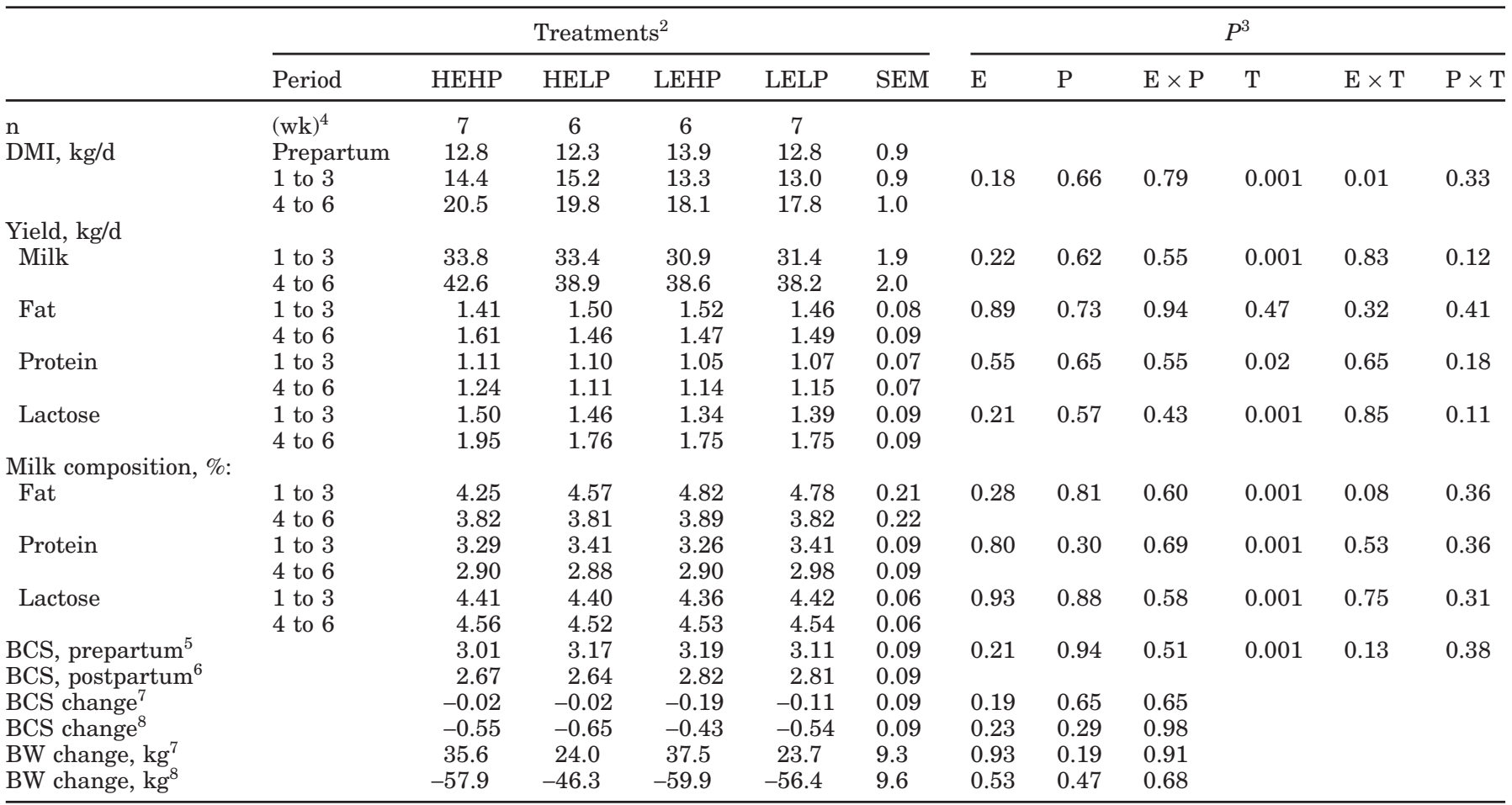

${ }^{1} \mathrm{LS}$ means are presented with the pooled standard error of the mean (SEM).

${ }^{2} \mathrm{HEHP}=$ High energy and high protein, HELP = high energy and low protein, LEHP = low energy and high protein, LELP = low energy and low protein.

${ }^{3}$ The statistical model contained pre- and postpartum data, and included period as a repeated measure; $P$-value for treatment and time effects: $\mathrm{E}=$ energy, $P$ = protein, $\mathrm{T}$ = period.

${ }^{4}$ Refers to weeks postpartum.

${ }^{5}$ Mean BCS from 3 wk precalving to calving.

${ }^{6}$ Mean BCS from calving to 6 wk postcalving.

${ }^{7}$ Difference between pretreatment data and calving data.

${ }^{8}$ Difference between calving data and data at 6 wk postcalving.

0.05). When HE was associated with $\mathrm{HP}, \mathrm{ADF}$ digestibility was higher than it was when associated with LP; however, when LE was associated with HP, ADF digestibility was lower than when it was associated with LP. Neutral detergent fiber digestibility was higher for the HP diets $(61.1 \%)$ than the LP diets (55.5\%). There were no treatment effects on nutrient digestibility in the postpartum period.

\section{DISCUSSION}

\section{Lipid Metabolism and Metabolic Parameters}

The gradual increase in plasma NEFA concentrations from wk-3 to wk-1 (Figure 5) has been suggested as a feed intake effect, while the rapid increase in the immediate precalving period may be hormonally regulated (Grummer, 1993). Force-feeding cows during the transition period attenuated the rise in plasma NEFA at calving but did not completely eliminate it (Bertics et al., 1992), suggesting that hormonal control plays a role. VázquezAñón et al. (1994) suggested that the spike at calving was associated with the sharp reduction in intake and with the elevation in plasma lipolytic hormones that occurs in conjunction with the onset of calving. Data from the present study appear to support these hypotheses because the change in NEFA during the week precalving was negatively correlated with the change in DMI, and NEFA concentrations during the week precalving and at calving were negatively correlated with energy balance. The LEHP cows, which had the highest NEFA at calving, experienced the largest drop in intake precalving and were in the most negative energy balance. The cow with the lowest intake at calving $(2.9 \mathrm{~kg})$ had the highest NEFA concentration $(2172 \mu \mathrm{mol} / \mathrm{L})$.

Plasma NEFA 1 to $2 \mathrm{~d}$ precalving are highly correlated with liver TG $1 \mathrm{~d}$ postcalving (VandeHaar et al., 1999). At high circulating concentrations, large amounts of NEFA entering the liver are esterified due to physiological lim- 

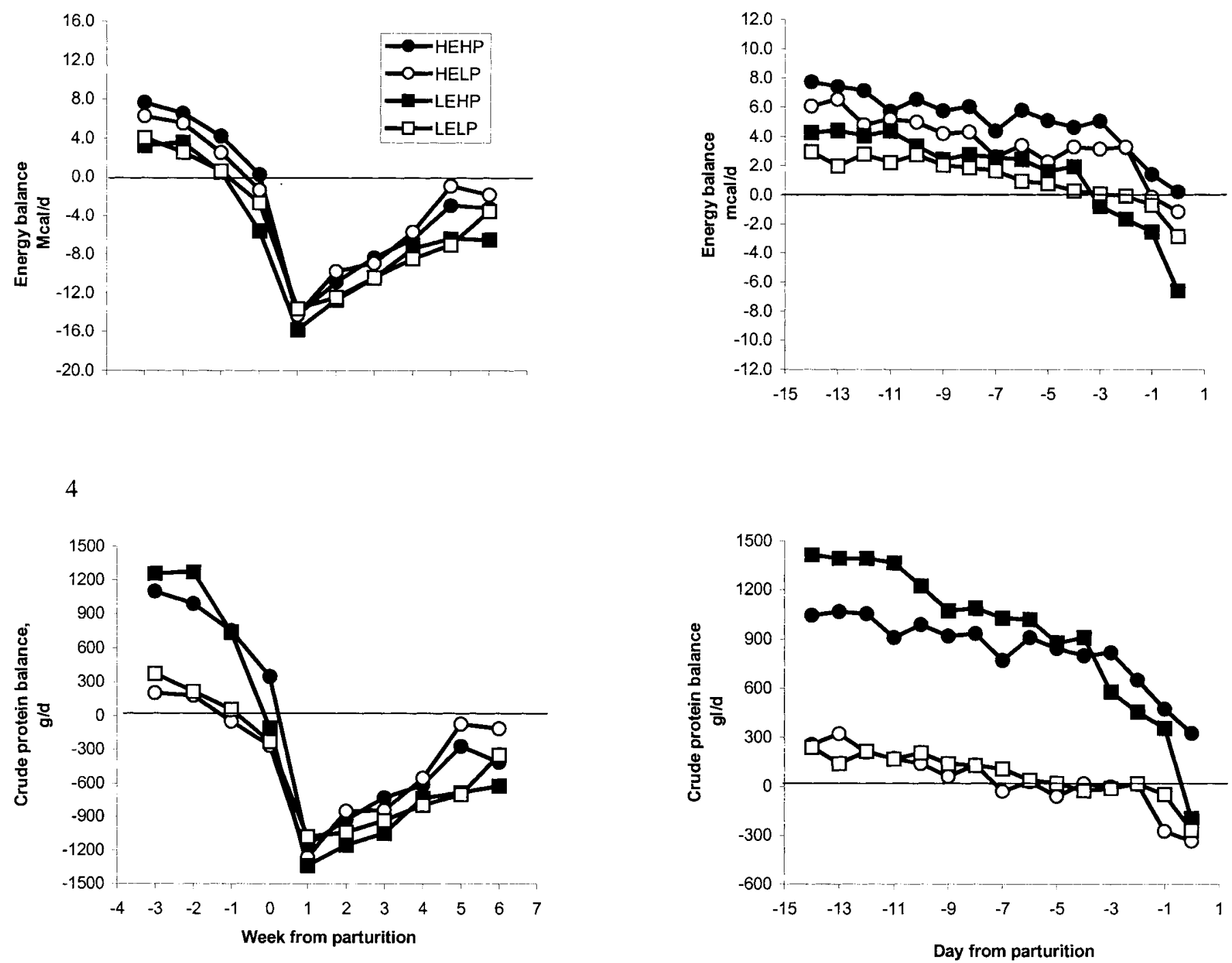

Figure 12. Net energy balance (top panel; pooled SEM = 1.61) and CP balance (bottom panel; pooled $\mathrm{SEM}=169$ ). Treatment effects for energy balance: energy, $P=0.003$. Treatment effects for protein balance: protein, $P=0.006$; protein $\times$ week, $P<0.0001$. Cows were fed diets for $21 \mathrm{~d}$ before calving that contained a high (HE) or low (LE) concentration of energy and a high (HP) or low (LP) concentration of protein. All cows were fed the same diet postcalving. The data for week, with the exception of wk 0, represent the average of $7 \mathrm{~d}$. The data for wk 0 were obtained from the day of calving only.

its to oxidation (Goff and Horst, 1997) and TG accumulate as a result of the liver's limited capacity to export TG as very low density lipoproteins (Grummer, 1993; Drackley, 1999). Accordingly, in the present study, lower liver TG content at d $1(\sim 40 \%)$ for HE treatment cows corresponded with lower NEFA. Because elevated hepatic lipid content is associated with an increased incidence of metabolic disorders (Grummer, 1993) feeding high-energy diets prepartum may offer benefits in terms of reducing postparturient disorders. Hepatic TG content was higher on $\mathrm{d} 21$ than $\mathrm{d} 1$ indicating that lipolysis and the release of NEFA were ongoing. Lipolytic rates reported by McNamara and Hillers (1986) substantiate this finding. The increase in hepatic TG from $\mathrm{d} 1$ to 21 was less than from $d-25$ to 1 , likely due to the substantially reduced plasma NEFA concentrations seen by 2 wk postpartum. These low concentrations probably result from high NEFA extraction by the mammary gland for milk fat synthesis. Bell (1995) estimated that in the immediate postpartum period, approximately $50 \%$ of circulating NEFA are either oxidized or incorporated into milk fat. Although liver TG concentrations were quite high, clinical signs of fatty liver or ketosis were not observed.

Liver glycogen concentration was not significantly influenced by prepartum energy intake, which con- 


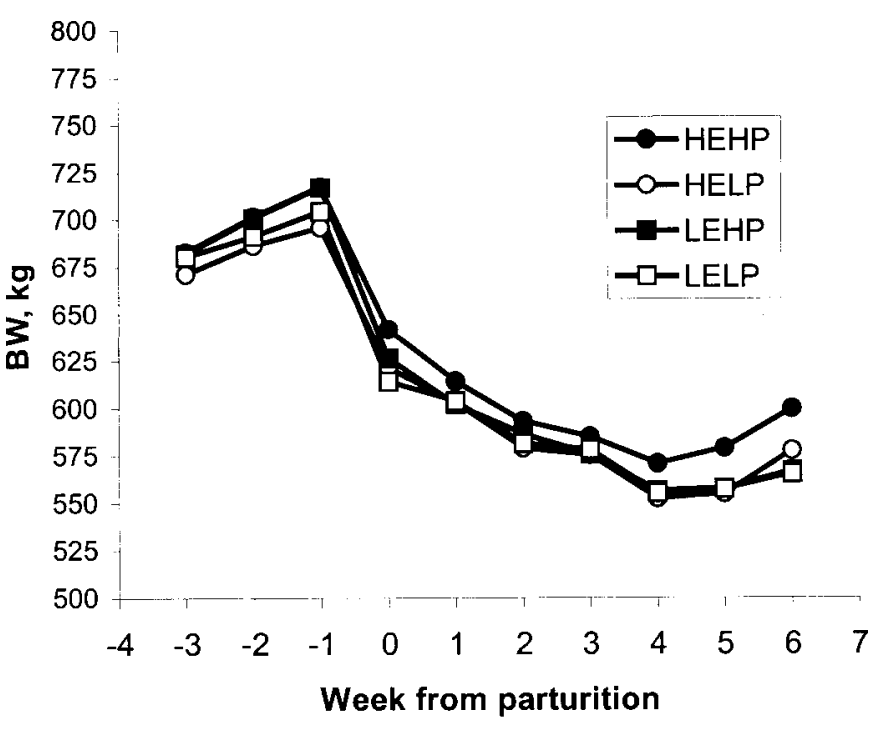

Figure 13. Bodyweight around the time of calving (pooled SEM $=11.1)$. There were no treatment effects $(P>0.05)$. Cows were fed diets for $21 \mathrm{~d}$ before calving that contained a high (HE) or low (LE) concentration of energy and a high (HP) or low (LP) concentration of protein. All cows were fed the same diet postcalving. Data were covariately adjusted for differences in pretreatment values. The data for calving (wk 0) were obtained within $24 \mathrm{~h}$ of calving.

trasts the findings of Minor et al. (1998), where cows that consumed more energy precalving had significantly higher hepatic glycogen content. Those authors hypothesized that the elevated glycogen content was related to the higher plasma glucose concentrations

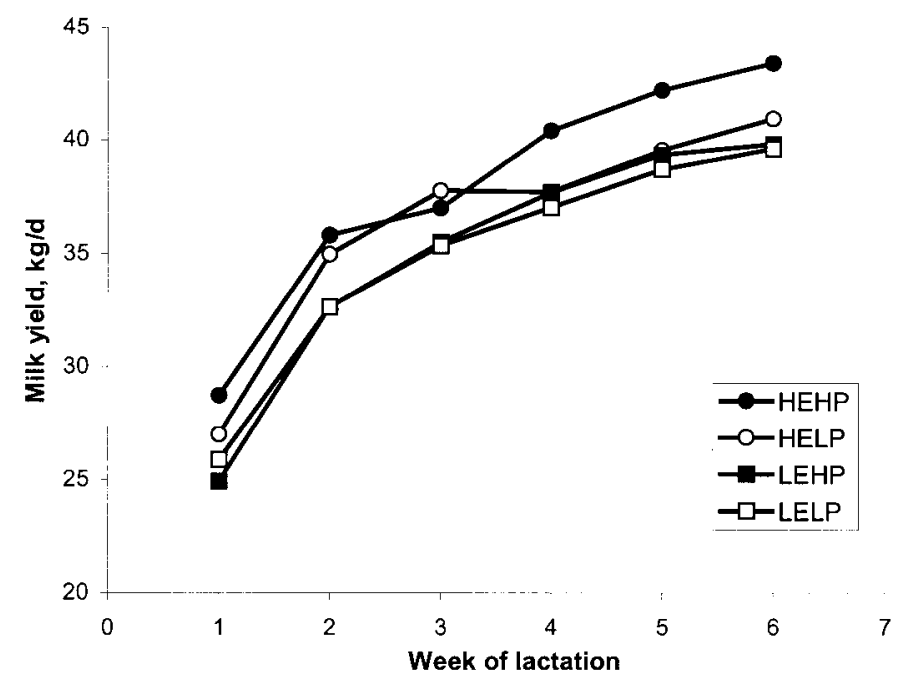

Figure 14. Milk yield during the first 6 wk postpartum (pooled SEM $=2.1)$. There were no treatment effects $(P>0.05)$. Cows were fed diets for $21 \mathrm{~d}$ before calving that contained a high (HE) or low (LE) concentration of energy and a high (HP) or low (LP) concentration of protein. All cows were fed the same diet postcalving.
Table 7. Milk fatty acid composition at 2 and 6 wk postpartum. ${ }^{1}$

\begin{tabular}{|c|c|c|c|c|}
\hline & \multicolumn{2}{|c|}{ Weeks postpartum } & \multirow[b]{2}{*}{ SEM } & \multirow[b]{2}{*}{$P^{2}$} \\
\hline & 2 & 6 & & \\
\hline \multicolumn{5}{|l|}{ Fatty acid, \% } \\
\hline $\mathrm{C} 4: 0$ & 2.09 & 1.96 & 0.05 & 0.10 \\
\hline C6:0 & 2.93 & 3.68 & 0.10 & 0.001 \\
\hline $\mathrm{C} 8: 0$ & 0.93 & 1.39 & 0.05 & 0.001 \\
\hline C10:0 & 1.70 & 2.85 & 0.12 & 0.001 \\
\hline C12:0 & 1.90 & 3.24 & 0.12 & 0.001 \\
\hline C14:0 & 7.25 & 10.25 & 0.29 & 0.001 \\
\hline C14:1 & 0.69 & 0.93 & 0.04 & 0.001 \\
\hline C15:0 & 0.82 & 1.06 & 0.03 & 0.001 \\
\hline C16:0 & 27.64 & 27.59 & 0.20 & 0.86 \\
\hline C16:1 & 2.69 & 2.24 & 0.07 & 0.001 \\
\hline C18:0 & 12.06 & 10.25 & 0.28 & 0.001 \\
\hline C18:1 & 29.67 & 24.35 & 0.58 & 0.001 \\
\hline $\mathrm{C} 18: 2$ & 2.26 & 2.02 & 0.06 & 0.009 \\
\hline C18:3 & 0.44 & 0.41 & 0.01 & 0.12 \\
\hline C20:0 & 0.19 & 0.21 & 0.01 & 0.13 \\
\hline C20:1 & 0.39 & 0.46 & 0.02 & 0.006 \\
\hline C20:4 & 0.14 & 0.12 & 0.005 & 0.001 \\
\hline C20:5 & 0.04 & 0.07 & 0.007 & 0.004 \\
\hline $\mathrm{C} 22: 0$ & 0.09 & 0.11 & 0.008 & 0.05 \\
\hline $\mathrm{C} 22: 1$ & 0.09 & 0.07 & 0.03 & 0.52 \\
\hline Short chain ${ }^{3}$ & 18.32 & 25.37 & 0.70 & 0.001 \\
\hline Medium chain ${ }^{4}$ & 30.33 & 29.83 & 0.22 & 0.10 \\
\hline Long chain ${ }^{5}$ & 46.19 & 38.76 & 0.77 & 0.001 \\
\hline
\end{tabular}

${ }^{1} \mathrm{LS}$ means are presented with the pooled standard error of the mean (SEM).

${ }^{2} P$-value for week.

${ }^{3}$ Includes $\mathrm{C} 4: 0$ to $\mathrm{C} 15: 0$.

${ }^{4}$ Includes $\mathrm{C} 16: 0$ and $\mathrm{C} 16: 1$.

${ }^{5}$ Includes C18:0 to C22:1.

seen in those cows. In our study, plasma glucose was not affected by treatment. If hepatic glycogen content is indicative of carbohydrate status, then the carbohydrate status of the cows was not influenced by prepartum diet, but was negatively impacted by parturition and the onset of lactogenesis.

Hippen et al. (1999) demonstrated that the ratio of hepatic TG to glycogen increased from parturition to $21 \mathrm{~d}$ postpartum. This is likely a reflection of the cow's negative energy balance and the resultant mobilization of lipid reserves and depletion of hepatic glycogen reserves. In our study, there was a strong negative correlation between hepatic TG and glycogen. The TG:glycogen ratio increased from 0.08 on $\mathrm{d}-25$ to 2.77 on $\mathrm{d} 1$ and 3.72 on $\mathrm{d} 21$. The ratio was numerically smaller for the HE treatments compared with the LE treatments as a result of the significantly lower TG content and numerically higher glycogen content of cows on the HE treatments on d 1. Drackley et al. (1992) have suggested that cows with a TG:glycogen ratio greater than 2:1 are susceptible to development of fatty liver and ketosis. This suggestion was based on observations of ketosis induction (KI) studies (Drackley et al., 1992; Veenhuizen et al., 1991), in which cows subjected to the KI 
Table 8. Digestibility of nutrients in cows fed different diets prepartum. ${ }^{1}$

\begin{tabular}{|c|c|c|c|c|c|c|c|c|}
\hline & \multicolumn{4}{|c|}{ Treatments $^{2}$} & \multirow[b]{2}{*}{ SEM } & \multicolumn{3}{|c|}{$P^{3}$} \\
\hline & HEHP & HELP & LEHP & LELP & & $\mathrm{E}$ & $\mathrm{P}$ & $\mathrm{E} \times \mathrm{P}$ \\
\hline \multicolumn{9}{|c|}{ Prepartum digestibility, $\%$} \\
\hline $\mathrm{DM}$ & 71.4 & 67.2 & 64.0 & 64.0 & 1.4 & 0.002 & 0.15 & 0.18 \\
\hline $\mathrm{OM}$ & 74.7 & 70.5 & 66.5 & 67.2 & 1.4 & 0.001 & 0.23 & 0.11 \\
\hline $\mathrm{CP}$ & 71.1 & 61.0 & 68.0 & 61.4 & 2.0 & 0.52 & 0.001 & 0.42 \\
\hline $\mathrm{ADF}$ & 54.7 & 45.1 & 49.7 & 51.3 & 2.6 & 0.81 & 0.15 & 0.05 \\
\hline NDF & 63.7 & 55.1 & 58.5 & 55.9 & 2.3 & 0.33 & 0.03 & 0.22 \\
\hline \multicolumn{9}{|c|}{ Postpartum digestibility, $\%$} \\
\hline $\mathrm{DM}$ & 73.8 & 76.1 & 74.1 & 74.4 & 2.0 & 0.74 & 0.52 & 0.66 \\
\hline $\mathrm{OM}$ & 76.1 & 77.8 & 75.9 & 76.8 & 1.8 & 0.75 & 0.49 & 0.83 \\
\hline $\mathrm{CP}$ & 74.3 & 76.9 & 74.9 & 75.4 & 1.9 & 0.84 & 0.43 & 0.61 \\
\hline $\mathrm{ADF}$ & 55.4 & 51.5 & 48.2 & 49.8 & 2.3 & 0.09 & 0.62 & 0.26 \\
\hline $\mathrm{NDF}$ & 64.4 & 61.0 & 59.7 & 63.1 & 1.8 & 0.49 & 0.99 & 0.10 \\
\hline
\end{tabular}

protocol had pretreatment ratios of greater than 2:1, whereas control cows had lower ratios. However, it is not known whether the control cows would have developed ketosis had they been subjected to the protocol. The TG:glycogen ratio may give an indication of the susceptibility of cows to develop ketosis following a KI protocol, but may not indicate a cow's susceptibility to spontaneous ketosis under normal feeding conditions.

The higher plasma BHBA concentrations postpartum vs. prepartum (Figure 1) are consistent with VázquezAñón et al. (1994). In contrast to plasma NEFA, BHBA concentrations were higher at wk 1 postpartum than at parturition. Perhaps this lag time exists because NEFA provide the substrate for BHBA synthesis. Cows on the LEHP treatment, who had the highest NEFA at calving, had the numerically highest BHBA at wk 1 . Cows fed the HP diets had elevated BHBA concentrations compared with cows fed LP. If the cow's priority for nutrients is the mammary gland, milk synthesis will occur if protein is available even when energy is limiting. It may be possible that the cows that were fed the HP diets precalving had more mobilizable protein reserves, and this promoted greater lipid mobilization. If lipolysis occurred at a rate that exceeded the liver's capacity to completely oxidize or esterify the NEFA, then BHBA concentrations would rise.

Glucose concentrations that peaked at calving and were lower postpartum than prepartum (Figure 2) arecommon (Vázquez-Añón et al., 1994; Dann et al., 1999). The peak at calving may be related to the release of glucocorticoids immediately before calving that stimulate glycogenolysis and gluconeogenesis (Vázquez-Añón et al., 1994). The decreased glucose concentrations postpartum are probably related to low DMI, and the con- comitant reduction in propionate absorption, along with an increased glucose requirement for milk synthesis.

Over the course of the trial, insulin concentrations were lower when dietary energy and protein were uncoupled (Figure 3). With the HE diets, high concentrations of propionate would be expected. Propionate is an insulin secretagogue. Because protein is also an insulin secretagogue, it is not surprising that the HEHP diets would result in elevated insulin concentrations relative to HELP. It is unknown why the LELP diet would result in higher insulin levels than the LEHP diet.

Prepartum dietary treatment had no effect on the concentration of IGF-1 and GH, but the change in their profiles is indicative of homeorhetic adaptation of the dairy cow during late pregnancy and lactation (Figure 4). The elevation in GH concentration as parturition approaches directs nutrients away from adipose tissue and toward tissues such as the fetus and mammary gland. The uncoupling of IGF-1 and GH is similar to that reported by VandeHaar et al. (1999) and Grum et al. (1996).

To our knowledge this is the first study that has examined ACC and FAS protein abundance in adipose tissue of the transition cow. The higher ACC and FAS abundance on $\mathrm{d} 1$ in cows fed the HE diets prepartum vs. cows fed LE is probably a reflection of the cows' energy balance. Cows on the LE diets had already been in negative energy balance for $4 \mathrm{~d}$, while cows on the $\mathrm{HE}$ diets were only in negative energy balance for 1 d. On d 21 there were no differences in ACC protein abundance due to treatment. Obviously the need for energy substrates by the mammary gland supercedes any effect of prepartum treatment. The values for ACC abundance on d 21 are similar to those reported by 
Beswick and Kennelly (1998) for cows in midlactation receiving GH or GH releasing factor. It is not surprising that the values would be similar. Growth hormone inhibits insulin stimulated lipogenesis and enhances lipolysis (Bauman and Currie, 1980). A similar situation is seen in early lactation. Growth hormone is elevated around calving, adipose tissue is insensitive to the actions of insulin, and lipogenesis is severely inhibited. McNamara and Hillers (1986) measured the rate of lipogenesis in adipose tissue slices and found that the rate at 2 wk postpartum was only $5 \%$ of the rate at 1 mo prepartum.

The change in FAS protein abundance from $d-25$ to 21 was similar to that of ACC and reflects the reduced lipogenesis around parturition. The abundance of FAS on $\mathrm{d} 21$ was only $7.8 \%$ of the value on $d-25$. This reduction in abundance coincides with the change in lipogenic rates reported by McNamara and Hillers (1986). Fatty acid synthase is regulated primarily at the level of transcription (Goodridge, 1986). Insulin stimulates FAS expression in adipocytes by increasing the transcription rate of the gene (Claycombe et al., 1998); thus, the low levels of insulin in the periparturient period would account, in part, for the low FAS protein content postpartum. The elevated GH concentrations observed postpartum may also contribute to the reduced FAS protein abundance. Porcine FAS mRNA content was significantly reduced in adipose tissue by administration of GH (Mildner and Clarke, 1991).

The activities of ACC, FAS, and LPL were unaffected by treatment but were affected by physiological state (Table 4). The activity of ACC on d 21 was only $7 \%$ that of $\mathrm{d}-25$. This effect is probably mediated by $\mathrm{GH}$ and insulin. Rapid regulation of ACC occurs through covalent modification. The enzyme is active when dephosphorylated, and insulin is a potent stimulator of dephosphorylation. During the periparturient period, insulin concentrations are low and GH concentrations are high, rendering insulin inactive and preventing it from activating ACC. Insulin also stimulates LPL (Faulconnier et al., 1994), but because adipose tissue is insensitive to the action of insulin in early lactation LPL activity is reduced. NEFA are also thought to inhibit LPL activity (Fielding and Fielding, 1991). The reduction in FAS activity from the prepartum period to the postpartum period is in agreement with the decline in FAS abundance.

\section{Protein Metabolism}

Higher prepartum PUN concentrations for cows on the HP diets vs. those on LP (Figure 8), are similar to findings of Huyler et al. (1999) and Greenfield et al.
(2000). Elevated PUN concentrations are indicative of increased ureagenesis, a result of oxidation of amino acids in excess of those required for protein synthesis, or of detoxification of absorbed ammonia (Lobley et al., 2000). The more positive protein balance of the cows on the HP treatments also indicates that protein, either rumen degradable or rumen escape, may have been supplied in excess of requirement for the majority of the prepartum period. As parturition approached, PUN declined, consistent with the reduction in dietary protein intake.

The effect of dietary treatment on plasma 3-MH was opposite that on PUN. Prepartum 3-MH concentration was higher for the LP cows compared with HP (Figure 9 ), and peaked at calving for the LP cows but at 1 wk postcalving for the HP cows. These results suggest differences in protein metabolism between the two groups, since 3-MH is released upon protein degradation, primarily from skeletal muscle (Young and Munro, 1978). The higher concentration and earlier peak in the LP cows indicates that skeletal muscle protein was being degraded earlier in gestation and to a greater extent in these cows. Regardless of treatment, it appears that the greatest demand for AA, relative to supply, is at calving and the first week postpartum. The period of greatest negative protein balance also occurred at $1 \mathrm{wk}$ postpartum. Postpartum, the 3-MH concentrations were similar among the treatment groups, suggesting that there was no residual effect of prepartum dietary supply, and that mobilization of body stores was equal across treatments. It appears that greater body protein reserves prepartum do not allow for greater protein mobilization postpartum.

The ratio of urinary $3-\mathrm{MH}$ to creatinine has been used as a measure of protein degradation standardized for muscle mass (Simmons et al., 1994). The ratio in the prepartum period was not altered by treatment, suggesting that protein degradation was similar among the treatments. This contrasts the study of VandeHaar et al. (1999), in which increasing the energy and protein content of the diet increased the 3-MH:creatinine ratio. Those authors suggested that the increased muscle protein degradation occurred in conjunction with increased protein synthesis, and that the more nutrient-dense diet supported greater amounts of protein synthesis. Insulin and GH concentrations were not reported in that study, but that data may have helped to substantiate that speculation. The reduction in plasma insulin before calving in our study would not support the idea of increased muscle protein synthesis.

That the 3-MH:creatinine ratio was highest at $10 \mathrm{~d}$ postcalving and started to decline thereafter is consistent with the data of Simmons et al. (1994). The high postpartum ratio suggests that protein degradation 
was higher after calving than before calving, however, it is not known when the increase in degradation began. Urine samples were not obtained at calving, so the possibility that the urinary 3-MH:creatinine ratio was highest at calving exists, and would be in agreement with the plasma 3-MH data.

Cows were at their lowest BW at wk 4 postpartum. At that time postpartum, average weight loss of cows across all treatments was $67 \mathrm{~kg}$. Assuming that protein constitutes $\sim 15 \%$ of BW (Botts et al., 1979; Andrew et al., 1995), then body protein loss averaged $10 \mathrm{~kg}$, in agreement with the value of Belyea et al. (1978). Motyl and Barej (1986), using urinary 3-MH output, calculated that protein degradation was $434 \mathrm{~g} / \mathrm{d}$ from 5 to 10 DIM, and $380 \mathrm{~g} / \mathrm{d}$ from 25 to 30 DIM. Based on these values, protein degradation during the first 28 DIM in our study would be $11.7 \mathrm{~kg}$. If it is assumed that all this protein is used for milk protein synthesis $(80 \%$ efficiency; Tamminga et al., 1997), then $334 \mathrm{~g} / \mathrm{d}$ of milk protein could be produced, which is enough to support $10 \mathrm{~kg}$ of milk with $3.3 \%$ protein.

Glutamine and Gly concentrations increased at $2 \mathrm{~d}$ precalving, indicative of muscle protein mobilization (Verbeke et al., 1972). Skeletal muscle stores large amounts of these AA, and upon degradation, releases them in substantial amounts relative to the other AA. At calving, the majority of the AA decreased in concentration (Table 5). Meijer et al. (1995) reported a similar decline. The fall in concentration is likely due to utilization of the AA for gluconeogenesis and milk protein synthesis. The onset of lactation is associated with increased AA uptake by the mammary gland and liver (Verbeke et al., 1972). The rise in concentration by d 21 of most of the AA may be a reflection of increased protein supply either through increases in DMI and/or muscle protein degradation. Histidine and Phe were the only EAA that exhibited a decline in concentration from $d 1$ to 21. Evaluation of the postpartum diet with CNCPS (O'Connor et al., 1993) indicated that these two AA were supplied in excess of requirements, so an increase in concentration, or at least maintenance of concentration, would have been expected. Glutamine was the only NEAA that was lower on d 21 than on d 1. Based on similar observations, Meijer et al. (1995) suggested that Gln was limiting for milk protein synthesis. Considering that Gln also serves as a gluconeogenic substrate and an energy source for the gut, and is critical in the maintenance of immunological functions, it may be possible that it is limiting in early lactation.

\section{DMI, BW, BCS, and Energy and Protein Balance}

The substantial drop in intake with all treatments during the week preceding calving is consistent with previously published results (Van Saun et al., 1993; Dann et al., 1999; Greenfield et al., 2000), and may be a result of physical limitations and endocrine changes associated with parturition and lactogenesis (Grummer, 1993). Over the prepartum period, intake was similar between the HE and LE cows, while during the postpartum period, cows on the HE diets prepartum consumed more feed than cows on the LE diets, suggesting that feeding prepartum diets with a net energy content as high as $1.65 \mathrm{Mcal} / \mathrm{kg}$ does not limit prepartum intake and may have beneficial effects on postpartum DMI.

The energy balance of cows on the HE treatments was improved throughout the prepartum and postpartum periods. Because DMI was equivalent between the HE and LE animals prepartum, the higher energy density of the HE diets increased energy intake and hence energy balance of the HE cows. Based on NRC requirements (1989), HE cows were in positive energy balance until the day of calving, whereas the LE cows were in negative energy balance by the third day prepartum. Consistent with the improved energy balance of the $\mathrm{HE}$ cows was the reduction in plasma NEFA (VandeHaar et al., 1999), the greater abundance of ACC and FAS on $\mathrm{d} 1$, and the lower hepatic TG content relative to the LE cows. Cows on the LE diets lost 0.15 BCS units between the initiation of treatment and calving, indicating that the NRC (1989) requirements may be low because the LE diets were slightly more energy dense than that recommended by NRC. VandeHaar et al. (1999) have also suggested that the NRC requirements may be too low. Indeed, NRC (2001) has raised the net energy density required for the transition cow diet to $1.62 \mathrm{Mcal} / \mathrm{kg}$. The rationale behind this increase was the recognition of the decline in DMI of the prefresh cow, the increased energy requirements for mammary growth (although not quantified), as well as the potential beneficial effects on rumen development (VFA production and papillae growth) and a possible reduction in lipid mobilization (NRC, 2001).

The higher postpartum DMI of cows on the HE treatments resulted in higher energy intakes of these cows. This was reflected in a less negative energy balance (Figure 12). However, the higher prepartum CP intake of cows on the HP treatments did not influence postpartum CP intake. Putnam and Varga (1998) also found that postpartum intake was unaffected by prepartum protein intake. Similarly, in the study of Putnam et al. (1999), in which prepartum dietary CP concentrations were similar to those in the present study, postpartum DMI was not different between the two treatment groups. That cows were in negative protein balance postpartum until 42 DIM contrasts with Grummer (1995), who calculated the CP balance of cows in the 
study of Bertics et al. (1992) and found that the cows regained positive protein balance by $7 \mathrm{~d}$ postpartum. This discrepancy may be due to differences in protein content of the diet, DMI, and/or milk protein yield.

\section{Milk Yield and Composition}

Prepartum dietary energy and protein levels had no significant effects on milk yield, an observation often reported by others (VandeHaar et al., 1999; Dewhurst et al., 2000; Holcomb et al., 2001). It would appear that the reliance on mobilization of body tissue to support milk synthesis modulates the effect of prepartum treatment. During the first 3 wk postpartum, cows on the $\mathrm{HE}$ treatments averaged $2.4 \mathrm{~kg}$ more milk than cows on LE; however, this difference was not significant. Huyler et al. (1999) reported a $3 \mathrm{~kg}$ difference in milk yield between their prepartum dietary treatments $(\mathrm{n}=$ 12), but this also did not reach significance. Both of these studies demonstrate the need for a large number of cows to detect differences in milk production. After 21 DIM, cows on the HEHP treatment continued to increase their milk yield relative to cows on the LE treatments, but cows on HELP only produced the same amount of milk as the LE cows. This was caused by a lack of a milk yield increase from wk 3 to 4 , which was probably related to the tissue biopsies at $d 21$. Some cows in each treatment experienced a temporary reduction in milk yield following the biopsies, but the effect appeared to be more pronounced and long-lasting in the HELP cows, likely related to a drop in intake for a few days after the biopsies. This suppression of DMI may be a response to inflammation. Several of the cows, in all treatments, became infected at their adipose tissue biopsy sites and required drainage of the exudate.

Milk fat content during the first 21 DIM tended to be lower in cows fed HE than LE, but was not different during d 22 to 42 (energy $\times$ time interaction, $P=0.08$ ). This may be a direct reflection of plasma NEFA concentrations, as Pullen et al. (1989) found a positive correlation between milk fat content and plasma NEFA. Milk FA composition did not differ among treatments but did differ with time postpartum. There was a shift from long-chain to short-chain FA from wk 2 to wk 6 . The relative proportion of $\mathrm{C} 16$ remained unchanged. This change in FA profile represents a shift between de novo FA synthesis in the mammary gland and direct uptake of NEFA from plasma. At wk 2 compared with wk 6, cows are in more negative energy balance, plasma NEFA are higher, lipogenesis is reduced, and lipolysis is enhanced. This would encourage more direct incorporation of preformed long-chain FA and less de novo synthesis, as evidenced by the FA composition of milk fat at wh 2 more closely resembling that of adipose tissue (Rukkwamsuk et al., 2000) than does the composition at wk 6.

\section{Nutrient Digestibility}

An improvement in DM and OM digestibility, as observed with the HE diets, is commonly seen when concentrates replace forages in the diet. This effect may be attributed to an increase in starch content and a reduction in NDF (Valadares Filho et al., 2000). The improvement in $\mathrm{CP}$ digestibility of the HP diets compared with the LP diets is similar to that observed by Broderick et al. (2000). In that study, the inclusion of fishmeal in the diet increased $\mathrm{N}$ digestibility from 57.2 to $62.4 \%$. Dilution of metabolic fecal N may account for the increase in apparent $\mathrm{N}$ digestibility (Stallcup et al., 1975). The improvement in digestibility may also be due to higher ammonia production in the rumen (as evidenced by elevated PUN) with the HP diets. Broderick et al. (2000) also reported an increase in NDF digestibility with high protein diets as was observed in our study.

\section{CONCLUSIONS}

Prepartum diets containing $1.65 \mathrm{Mcal} / \mathrm{kg}$ of $\mathrm{NE}_{\mathrm{L}}$ increased postpartum DMI and improved energy balance of the cows prepartum and postpartum, but did not result in significantly higher milk yields compared with diets containing $1.3 \mathrm{Mcal} / \mathrm{kg}$ of $\mathrm{NE}_{\mathrm{L}}$. The $\mathrm{HE}$ diets also reduced plasma NEFA concentrations at calving and reduced hepatic TG content. Consistent with these changes was a reduction in ACC and FAS abundance in adipose tissue of cows fed the LE diets. Crude protein content of the prepartum diets did not affect any of these parameters. However, the $17.0 \%$ CP diets, compared with the $12.5 \% \mathrm{CP}$ diets, appeared to reduce muscle protein degradation, as evidenced by plasma $3-\mathrm{MH}$ content. The HP diets also resulted in higher PUN levels prepartum and elevated BHBA levels.

Feeding a HE diet for 3 wk prepartum has beneficial effects on energy metabolism, but these effects did not result in improvements in productivity in early lactation. Positive effects of high CP intake on productivity were negligible, although there were reductions in PUN and muscle protein degradation.

\section{ACKNOWLEDGMENTS}

The authors thank the staff at the University of Alberta Dairy Research and Technology Centre for animal care, Emma Norberg for assistance with sampling, and Naomi Beswick, Yan Meng, Sylvie Provencher, and Sandra Tymchuk for assistance with laboratory analyses. 


\section{REFERENCES}

Andrew, S. M., R. A. Erdman, and D. R. Waldo. 1995. Prediction of body composition of dairy cows at three physiological stages from deuterium oxide and urea dilution. J. Dairy Sci. 78:1083-1095.

Bauman, D. E., and W. B. Currie. 1980. Partitioning of nutrients during pregnancy and lactation: A review of mechanisms involving homeostasis and homeorhesis. J. Dairy Sci. 63:1514-1529.

Bell, A. W. 1995. Regulation of organic nutrient metabolism during transition from late pregnancy to early lactation. J. Anim. Sci. 73:2804-2819.

Belyea, R. L., G. R. Frost, F. A. Martz, J. L. Clark, and L. G. Forkner. 1978. Body composition of dairy cattle by potassium-40 liquid scintillation detection. J. Dairy Sci. 61:206-211.

Bertics, S. J., R. R. Grummer, C. Cadorniga-Valino, and E. E. Stoddard. 1992. Effect of prepartum dry matter intake on liver triglyceride concentration and early lactation. J. Dairy Sci. 75:19141922.

Beswick, N. S., and J. J. Kennelly. 1998. The influence of bovine growth hormone and growth hormone releasing factor on acetylCoA carboxylase and fatty acid synthase in primparous Holstein cows. Comp. Biochem. Physiol 120C:241-249.

Botts, R. L., R. W. Hemken, and L. S. Bull. 1979. Protein reserves in the lactating dairy cow. J. Dairy Sci. 62:433-440.

Broderick, G. A., R. P. Walgenbach, and E. Sterrenburg. 2000. Performance of lactating dairy cows fed alfalfa or red clover silage as the sole forage. J. Dairy Sci. 83:1543-1551.

Canadian Council on Animal Care. 1993. Guide to the Care and Use of Experimental Animals. Vol. 1, 2nd ed. E. D. Olfert, B. M. Cross and A. A. McWilliam, eds. CCAC, Ottawa, ON.

Claycombe, K. J., B. H. Jones, M. K. Standridge, Y. Guo, J. T. Chun, and J. W. Taylor. 1998. Insulin increases fatty acid synthase gene transcription in human adipocytes. Am. J. Physiol. 274R:12531259.

Dann, H. M., G. A. Varga, and D. E. Putnam. 1999. Improving energy supply to late gestation and early postpartum dairy cows. J. Dairy Sci. 82:1765-1778.

Dewhurst, R. J., J. M. Moorby, M. S. Dhanoa, R. T. Evans, and W. J. Fisher. 2000. Effects of altering energy and protein supply to dairy cows during the dry period. 1 . Intake, body condition, and milk production. J. Dairy Sci. 83:1782-1794.

Drackley, J. K. 1999. Biology of dairy cows during the transition period: The final frontier? J. Dairy Sci. 82:2259-2273.

Drackley, J. K., M. J. Richard, D. C. Beitz, and J. W. Young. 1992. Metabolic changes in dairy cows with ketonemia in response to feed restriction and dietary 1,3-butanediol. J. Dairy Sci. 75:1622-1634.

Faulconnier, Y., M. Thévenet, J. Fléchet, and Y. Chilliard. 1994. Lipoprotein lipase and metabolic activities in incubated bovine adipose tissue explants: effects of insulin, dexamethasone, and fetal bovine serum. J. Anim. Sci 72:184-191.

Fielding, P. E., and C. J. Fielding. 1991. Dynamics of lipoprotein transport in the circulatory system. Page 427 in Biochemistry of Lipids, Lipoproteins and Membranes. D. E. Vance and J. Vance, eds. Elsevier Science Publishers BV, Amsterdam.

Fenton, T. W., and M. Fenton. 1979. An improved method for the determination of chromic oxide in feed and feces. Can. J. Anim. Sci. 59:631-634.

Fletcher, M. J. 1968. A colorimetric method for estimating serum triglycerides. Clin. Chem. Acta 22:393-397.

Folch, J., M. Lees, and G. H. S. Stanley. 1957. A simple method for the isolation and purification of total lipids from animal tissues. J. Biol. Chem. 226:497-509.

Foster, L. B., and R. T. Dunn. 1973. Stable reagents for determination of serum triglycerides by a colorimetric Hantzsch condensation method. Clin. Chem. 19(3):338-340.

Goff, J. P., and R. L. Horst. 1997. Physiological changes at parturition and their relationship to metabolic disorders. J. Dairy Sci. 80:1260-1268.

Goodridge, A. G. 1986. Regulation of the gene for fatty acid synthase. Fed. Proc. 45:2399-2405.
Greenfield, R. B., M. J. Cecava, T. R. Johnson, and S. S. Donkin. 2000. Impact of dietary protein amount and rumen undegradability on intake, peripartum liver triglyceride, plasma metabolites, and milk production in transition dairy cattle. J. Dairy Sci. 83:703710.

Grum, D. E., J. K. Drackley, R. S. Younker, D. W. LaCount and J. J. Veenhuizen. 1996. Nutrition during the dry period and hepatic lipid metabolism of periparturient dairy cows. J. Dairy Sci. 79:1850-1864.

Grummer, R. R. 1993. Etiology of lipid-related metabolic disorders in periparturient dairy cows. J. Dairy Sci. 76:3882-3896.

Grummer, R. R. 1995. Impact of changes in organic nutrient metabolism on feeding the transition dairy cow. J. Anim. Sci. 73:2820-2833.

Hippen, A. R., P. She, J. W. Young, D. C. Beitz, G. L. Lindberg, L. F. Richardson, and R. W. Tucker. 1999. Alleviation of fatty liver in dairy cows with 14-day intravenous infusions of glucagon. J. Dairy Sci. 82:1139-1152.

Holcomb, C. S., H. H. Van Horn, H. H. Head, M. B. Hall and C. J. Wilcox. 2001. Effects of prepartum dry matter intake and forage percentage on postpartum performance of lactating dairy cows. J. Dairy Sci. 84:2051-2058.

Huyler, M. T., R. L. Kincaid, and D. F. Dostal. 1999. Metabolic and yield responses of multiparous Holstein cows to prepartum rumen-undegradable protein. J. Dairy Sci. 82:527-536.

Johnson, M. M., and J. P. Peters. 1993. Technical note: An improved method to quantify nonesterified fatty acids in bovine plasma. J. Anim. Sci. 71:753-756.

Khorasani, G. R., P. H. Robinson, G. De Boer, and J. J. Kennelly. 1991. Influence of canola fat on yield, fat percentage, fatty acid profile, and nitrogen fractions in Holstein milk. J. Dairy Sci. 74:1904-1911.

Lapierre, H., J. F. Bernier, P. Dubreuil, C. K. Reynolds, C. Farmer, D. R. Ouellet, and G. E. Lobley. 2000a. The effect of feed intake level on splanchnic metabolism in growing beef steers. J. Anim. Sci. 78:1084-1099.

Lapierre, H., C. Farmer, C. K. Reynolds, J. F. Bernier, G. E. Lobley, and P. Dubreuil. 2000b. The effect of intake level on whole body kinetics and hepatic removal of somatotropin in growing beef steers. Domest. Anim. Endocrinol. 18:217-227.

Liesman, J. S., J. P. McNamara, A. V. Capuco, M. Binelli, W. K. Vanderkooi, R. S. Emery, H. A. Tucker, and W. M. Moseley. 1995. Comparison of growth hormone-releasing factor and somatotropin: lipid and glucose metabolism in dairy cows. J. Dairy Sci. 78:2159-2166.

Lo, S., J. C. Russell, and A. W. Taylor. 1970. Determination of glycogen in small tissue samples. J. Appl. Physiol. 28(2):234-236.

Lobley, G. E., G. D. Milano, and J. G. Van der Walt. 2000. The liver: Integrator of nitrogen metabolism. Pages 149-168 in Ruminant Physiology: Digestion, Metabolism, Growth, and Reproduction. P. B. Cronjé, ed.

McNamara, J. P., and J. K. Hillers. 1986. Adaptations in lipid metabolism of bovine adipose tissue in lactogenesis and lactation. J. Lipid Res. 27:150-157.

Meijer, G. A. L., J. Van der meulen, J. G. M. Bakker, C. J. Van der koelen, and A. M Van vuuren. 1995. Free amino acids in plasma and muscle of high yielding dairy cows in early lactation. J. Dairy Sci. 78:1131-1141.

Mildner, A. M., and S. D. Clarke. 1991. Porcine fatty acid synthase: cloning of a complementary DNA, tissue distribution of its mRNA and suppression of expression by somatotropin and dietary protein. J. Nutr. 121:900-907.

Minor, D. J., S. L. Trower, B. D. Strang, R. D. Shaver, and R. R. Grummer. 1998. Effects of nonfiber carbohydrate and niacin on periparturient metabolic status and lactation of dairy cows. J. Dairy Sci. 81:189-200.

Moibi, J. A., R. J. Christopherson, and E. K. Okine. 2000. Effect of environmental temperature and dietary lipid supplement on activity and protein abundance of acetyl-CoA carboxylase and fatty acid synthase in skeletal muscle, liver and adipose tissue of sheep. Can. J. Anim. Sci. 80:69-77. 
Motyl, T., and W. Barej. 1986. Plasma amino acid indices and urinary 3-methyl histidine excretion in dairy cows in early lactation. Ann. Rech. Vet. 17:153-157.

National Research Council. 1989. Nutrient Requirements of Dairy Cattle. 6th rev. ed. Natl. Acad. Sci., Washington, DC.

National Research Council. 2001. Nutrient Requirements of Dairy Cattle. 7th rev. ed. Natl. Acad. Sci, Washington, DC.

O’Connor, J. D., C. J. Sniffen, D. G. Fox, and W. Chalupa. 1993. A net carbohydrate and protein system for evaluating cattle diets: IV. Predicting amino acid adequacy. J. Anim. Sci. 71:1298-1311.

Pullen, D. L., D. L. Palmquist, and R. S. Emery. 1989. Effect on days of lactation and methionine hydroxy analog on incorporation of plasma fatty acids into plasma triglycerides. J. Dairy Sci. $72: 49-58$.

Putnam, D. E., and G. A. Varga. 1998. Protein density and its influence on metabolite concentration and nitrogen retention by Holstein cows in late gestation. J. Dairy Sci. 81:1608-1618.

Putnam, D. E., G. A. Varga, and H. M. Dann. 1999. Metabolic and production responses to dietary protein and exogenous somatotropin in late gestation dairy cows. J. Dairy Sci. 82:982-995.

Rukkwamsuk, T., M. J. H. Geelen, T. A. M. Kruip, and T. Wensing. 2000. Interrelation of fatty acid composition in adipose tissue, serum, and liver of dairy cows during the development of fatty liver postpartum. J. Dairy Sci. 83:52-59.

SAS. 1999a. SAS/STAT User's Guide, Version 8. SAS Institute Inc., Cary, NC.

SAS. 1999b. SAS System for Mixed Models. SAS Institute Inc., Cary, NC.

Sedgwick, G. W., T. W. Fenton, and J. R. Thompson. 1991. Effect of protein precipitating agents on the recovery of plasma free amino acids. Can. J. Anim. Sci. 71:953-957.

Simmons, C. R., W. G. Bergen, M. J. VandeHaar, D. J. Sprecher, C. J. Sniffen, E. P. Stanisiewski, and H. A. Tucker. 1994. Protein and fat metabolism in cows given somavubove before parturition. J. Dairy Sci. 77:1835-1847.

Smart, M. E. 1985. Liver biopsies in cattle. Comp. Contin. Educ. Proc. Vet. 7:S327-332.
Stallcup, O. T., G. V. Davis, and L. Shields. 1975. Influence of dry matter and nitrogen intakes on fecal nitrogen losses in cattle. J. Dairy Sci. 58:1301-1307.

Tamminga, S., P. A. Luteijn, and R. G. M. Meijer. 1997. Changes in composition and energy content of liveweight loss in dairy cows with time after parturition. Livest. Prod. Sci. 52:31-38.

Valadares Filho, S. C., G. A. Broderick, R. F. D. Valadares, and M. K. Clayton. 2000. Effect of replacing alfalfa silage with high moisture corn on nutrient utilization and milk production. J. Dairy Sci. 83:106-114.

VandeHaar, M. J., G. Yousif, B. K. Sharma, T. H. Herdt, R. S. Emery, M. S. Allen, and J. S. Liesman. 1999. Effect of energy and protein density of prepartum diets on fat and protein metabolism of dairy cattle in the periparturient period. J. Dairy Sci. 82:1282-1295.

Van Saun, R. J., S. C. Idleman, and C. J. Sniffen. 1993. Effect of undegradable protein amount fed prepartum on postpartum production in first lactation Holstein cows. J. Dairy Sci. 76:236-244.

Van Soest, P. J., J. B. Robertson, and B. A. Lewis. 1991. Methods for dietary fiber, neutral detergent fiber and non-starch polysaccharide in relation to animal nutrition. J. Dairy Sci. 74:35833597.

Vázquez-Añón, M., S. Bertics, M. Luck, and R. R. Grummer. 1994. Peripartum liver triglyceride and plasma metabolites in dairy cows. J. Dairy Sci. 77:1521-1528.

Veenhuizen, J. J., J. K. Drackley, M. J. Richard, T. P. Sanderson, L. D. Miller, and J. W. Young. 1991. Metabolic changes in blood and liver during development and early treatment of experimental fatty liver and ketosis in cows. J. Dairy Sci. 74:4238-4253.

Verbeke, R., E. Roets, and G. Peeters. 1972. Variations in the concentrations of free amino acids in the plasma of the dairy cow at parturition. J. Dairy Res. 39:355-364.

Williamson, D. H. and J. Mellanby. 1974. D-(-)-3-Hydroxybutyrate. Page 1836 in Methods of Enzymatic Analysis. Vol. IV. V. R. Young and H. N. Munro. 1978. $\mathrm{N}^{\tau}$-Methylhistidine (3-methylhistidine) and muscle protein turnover: An overview. Fed. Proc. 37:22912300 .

Zurek, E., G. R. Foxcroft, and J. J. Kennelly. 1995. Metabolic status and interval to first ovulation in postpartum dairy cows. J. Dairy Sci. 78:1909-1920. 